This item was submitted to Loughborough's Research Repository by the author.

Items in Figshare are protected by copyright, with all rights reserved, unless otherwise indicated.

\title{
A 150-year record of coastline dynamics within a sediment cell: Eastern
}

\section{England}

PLEASE CITE THE PUBLISHED VERSION

http://dx.doi.org/10.1016/j.geomorph.2012.08.008

PUBLISHER

(C) Elsevier B.V.

VERSION

AM (Accepted Manuscript)

LICENCE

CC BY-NC-ND 4.0

\section{REPOSITORY RECORD}

Montreuil, Anne-Lise, and Joanna E. Bullard. 2019. "A 150-year Record of Coastline Dynamics Within a Sediment Cell: Eastern England”. figshare. https://hdl.handle.net/2134/11209. 
This item was submitted to Loughborough's Institutional Repository (https://dspace.lboro.ac.uk/) by the author and is made available under the following Creative Commons Licence conditions.

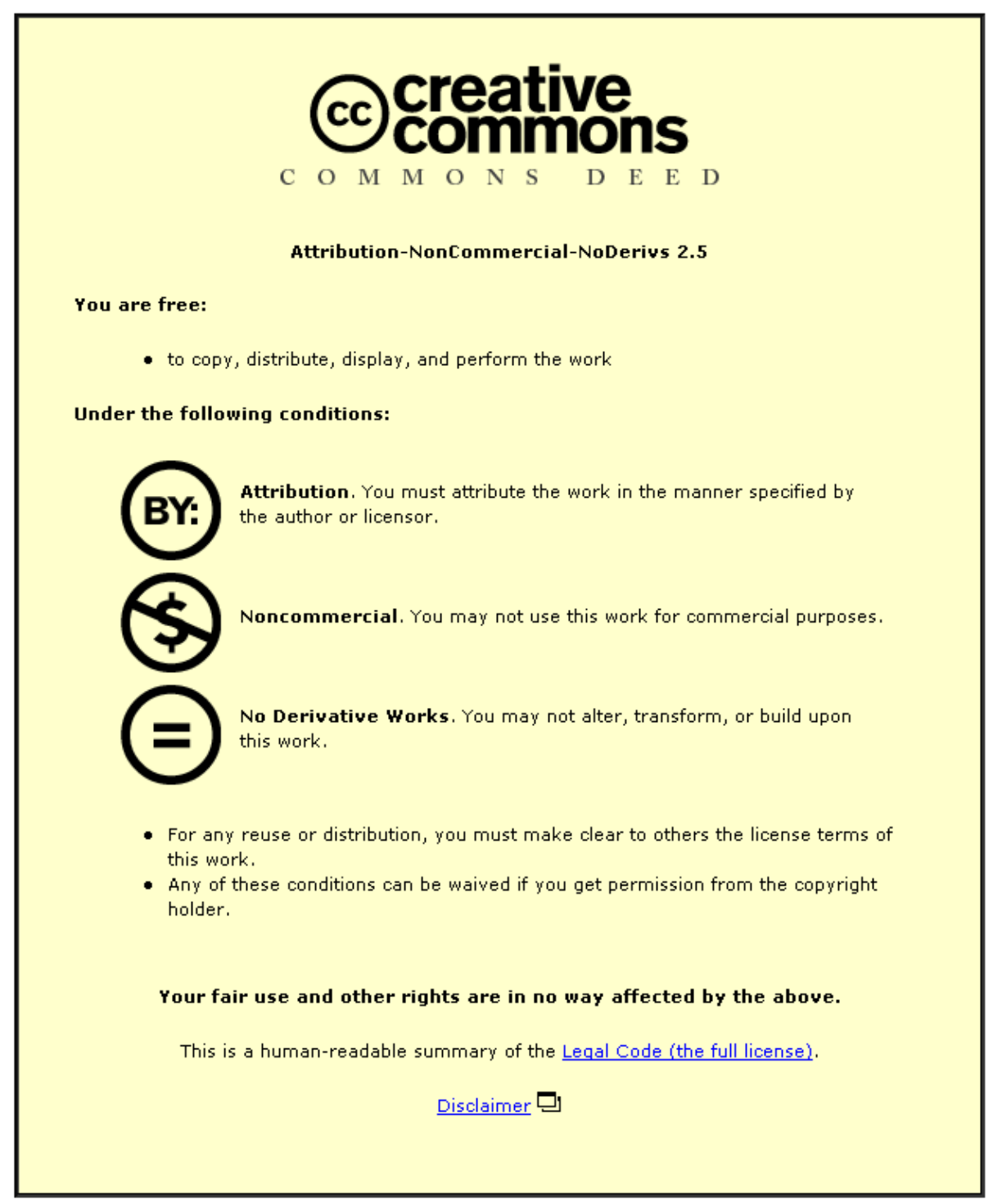

For the full text of this licence, please go to: http://creativecommons.org/licenses/by-nc-nd/2.5/ 
1 A 150-year record of coastline dynamics within a sediment cell: eastern England.

2

3

$4 \quad$ Anne-Lise Montreuil ${ }^{1}$, Joanna E. Bullard ${ }^{1 \star}$

5

$6 \quad{ }^{1}$ Department of Geography, Loughborough University, Leicestershire, LE11 3TU, UK.

$7 \quad$ Email: j.e.bullard@lboro.ac.uk

$8 \quad$ Tel: $+44(1) 509222794$

$9 \quad$ Fax: $+44(0) 1509223930$

10

$11{ }^{*}$ Corresponding author

12 
14 Coastal sediment cells reflect processes operating at a range of scales, but it is the medium spatial and temporal scales (decades to centuries) that are of greatest interest for coastal management. This paper focuses on coastline position change within a single sediment cell over 150 years where the geomorphology includes cliffs, beaches and saltmarshes. The focus is the east coast of England from Flamborough Head to Gibraltar Point. Although the updrift sector of this sediment cell has been studied for well over a century, the downdrift sector has attracted significantly less attention. Using topographic profiles, bathymetric profiles, aerial photographs and historical maps we mapped coastline erosion and accretion using the Digital Shoreline Analysis System (DSAS) and calculated volumetric changes for different morphometric units. Rapid erosion of the updrift Holderness cliffs has been counterbalanced with accretion on beaches along the downdrift Lincolnshire coast. The amount of accretion in Lincolnshire corresponds to around $29 \%$ of the volume of sediment eroded from Holderness. Much of the eroded cliff material is likely to be deposited temporarily into nearshore and offshore sand banks before being redistributed by crossshore currents. An exploration of storm surge impact on long-term erosion and accretion rates showed no clear relationship between storm surge frequency and change in coastline position, however this may be in part due to the relative timing of storm occurrence and data acquisition. The Jenkinson Daily Weather Type classification was found to be a reasonable proxy for the occurrence of strong onshore winds which may offer scope for further investigation of the role of forcing factors over time periods beyond the length of the meteorological and tidal station records. Winter North Atlantic Oscillation phase was not a good indicator of storminess on the east coast of England but may be a useful proxy for quiescence. 
39 Keywords Sediment cell, Coastline change, sediment budget, storm surge, Jenkinson 40 Weather Types

41

42

43 Highlights

44 1) Trends in the balance of sediment supplies and sinks in a littoral cell are examined.

45 2) Long-term erosion dominates cliffs updrift and reaches rates of up to $2 \mathrm{~m}$ year ${ }^{-1}$

3) Accretion up to $2.7 \mathrm{~m} \mathrm{yr}^{-1}$ dominates on sandy beaches at the centre of the cell.

47

4) The Jenkinson Daily Weather Type is a useful proxy for UK east coast storminess.

48 


\section{Introduction}

Coastlines are inherently dynamic landscape components and significant alterations in their position and alignment have been documented worldwide. These changes occur in response to factors such as sea-level change (Orford et al.,1995), large-scale morphological selforganization (Cooper et al., 2007), changes in sediment budget associated with sources (e.g. rivers, cliff erosion), sinks (e.g. sand banks, submarine canyons) and longshore transport (Pye, 1983; Aagaard et al., 2004), variations in storminess and wave climate (Zhang et al., 2001; Pye and Blott, 2008), and coastal management (Iskander et al., 2007; Kaminsky et al., 2010). Along any stretch of coastline, variations in the rate and direction (erosion or accretion) of change are common, associated with local sediment budget and coastal characteristics such as the distribution of headlands, cliffs and beaches; records of such dynamics are typically used to plan coastal management strategies. The importance of littoral sediment budget as a control on the direction of coastline movement is widely recognized and is typically linked to the concept of the sediment (or littoral) cell. Ideal sediment cells are sections of coast that are relatively self-contained and include defined sources, transport pathways and sinks of sediment. The concept was first applied to the California coast (Bowen and Inman, 1966; Inman and Frautschy, 1966) but is now widely used in countries such as the USA, Canada, New Zealand and the UK for coastal management planning, where cell boundaries define the planning units (e.g. Motyka and Brampton, 1993; Hooke and Bray, 1995; Cooper and Pontee, 2006).

The delimitation and operation of sediment cells reflect processes interacting at a range of spatial and temporal scales, and in many areas coastal morphology and dynamics still reflect and are recovering from the impact of Holocene sea-level changes and deglaciation (May and Hansom, 2003). It is the medium spatial ( $\geq 10 \mathrm{~km})$ and temporal (decades to centuries) scales that are usually of greatest interest for coastal management and forward planning 
(Cooper et al., 2001; Pethick, 2001; Orford and Pethick, 2006; Gelfenbaum and Kaminsky, 2010), but there is often a lack of systematic information concerning decadal-scale changes in interacting landforms within a single cell (e.g. Lee, 2001; Ruggiero et al., 2005; Pye et al., 2007). The aim of this paper is to quantify the spatial and temporal variability in coastline position, rate of change and sediment budget within a single sediment cell. Particular attention has been given to six areas of interest characterised by different coastal landforms (e.g. cliffs, beaches) or management intervention. We use complementary data sources including maps, aerial photographs and topographic profiles to document change over timescales up to 150 years. A preliminary examination of the relationship between morphological change and forcing factors is also presented. The area of interest is the east coast of England between Flamborough Head and Gibraltar Point. Whilst the northern part of this region has been widely-studied, the downdrift, southern sector has attracted significantly less attention.

\section{Regional setting}

Prior to the 1980s, coastal management in Britain was typically local in focus and determined by administrative bodies such as local authorities. Increasing recognition in the 1980s that management at one location can impact the coastline elsewhere led to various authorities combining interests to develop more integrated coastal management plans (Hooke and Bray, 1995). These coastal groups recognised the importance of understanding sediment transport patterns for effective management (e.g. Hooke and Bray, 1995; Hooke et al., 1996). Since the 1990s, the coastline of England and Wales has been divided in to eleven coastal cells (Motyka and Brampton, 1993) (Fig. 1). Each of these cells represents a defined natural sedimentary system and for each there is a Shoreline Management Plan (SMP) used to guide sustainable coastal defence decision-making processes (MAFF, 1994; DEFRA, 2006). SMPs involve numerous partner organisations and stakeholders including local authorities, government agencies and business and community groups, and their 
introduction marked a strategic step towards integrated management of the coastline within natural rather than purely administrative boundaries that is both long term and considers the impact of local-scale coastal management elsewhere (Hooke and Bray, 1995; O'Connor et al., 2009).

\subsection{Geomorphology of the coastal cell}

This paper focuses on sediment cell 2 along the East Riding and Lincolnshire coastlines, which is divided into three sub-cells (2a Flamborough Head to Spurn Head; 2b Outer Humber Estuary; 2c Donna Nook to Gibraltar Point: Fig. 1). Net longshore sediment transport is from north to south. The concept of sediment cells focuses on wave-driven transport of non-cohesive sediments (Motyka and Brampton, 1993) and is harder to apply to fine sediments in suspension (Hooke and Bray, 1995). However, many sediment cells include a variety of landforms including both those formed from non-cohesive sediments (such as sandy beaches) and those dominated by cohesive material such as saltmarshes. In the study area, coastal geomorphology within the cell is varied and includes chalk and glacial till cliffs, wide sandy beaches, saltmarshes, sand dunes, coastal spits and nearshore and offshore sand banks. Coastal management strategies include engineered defences built over the last two centuries and beach nourishment programmes, although large stretches of the coastline have no man-made defences. The main cell boundaries are Flamborough Head to the north, a fixed chalk headland, and Gibraltar Point spit in the south, which is a partial boundary with sediment transfer continuing in to The Wash and southern North Sea.

\section{$<$ Fig. 1>}


In the north of the sediment cell, glacial till cliffs $3-40 \mathrm{~m}$ high extend $60 \mathrm{~km}$ along the

127 Holderness coast and are rapidly retreating (recently reviewed by Quinn et al., 2009). The cliff erosion occurs through repeated landslide activity, caused mainly by waves undercutting the base of the cliffs and removing beach material (Dossor, 1955; Quinn et al., 2009). Sea defences are present near some coastal towns. Sediment eroded from these cliffs and the shore platform are transported southwards to Spurn Head and to offshore sand banks by littoral drift and wave currents. Spurn Head is a narrow sand and gravel spit that extends 5.5 $\mathrm{km}$ into the mouth of the Humber Estuary (sub-cell 2b). The Humber Estuary mouth stretches from Spurn Head to Donna Nook and is influenced both by the tide and flow from the river. Strong tidal flows intersect the north-south sediment transport pathway along the open coast, limiting the entry of gravels and sands into the estuary mouth.

In contrast, the low-lying Lincolnshire coast, south of the Humber, comprises superficial deposits left by retreating ice sheets (Swinnerton and Kent, 1949; Brampton and Beven, 1987) and is characterized by sandy beaches and saltmarshes (sub-cell 2c). Offshore sand banks are present from Donna Nook to Mablethorpe, and not only protect the shore against wave attack, but also provide a source of sand to the beaches which are up to $3.5 \mathrm{~km}$ wide and backed by dunes (van Houwelingen et al., 2006). Extensive saltmarshes at Saltfleetby are sheltered by broad beaches. This section of the Lincolnshire coastline is typically accreting (HR Wallingford, 2002). South of Mablethorpe the sediment budget changes and coastal erosion dominates in part due to the absence of offshore sand banks (Dugdale and Vere, 1993). Sea defences have been built to protect against coastal flooding and, following a severe storm surge in 1953, extensive 'hard' defences were built such as seawalls, groynes and revetments particularly near Skegness. Historically, during high storms, the thin sand cover on the beach moved seaward and the underlying glacial till was exposed and eroded. To counter this erosion, a major beach renourishment plan began in 1994 and continues to date (Environment Agency, 2004). Just south of Skegness, the coastline 
changes orientation slightly providing a sheltered coast for the development of coastal dunes and saltmarshes at Gibraltar Point (National Nature Reserve).

\subsection{Marine and climatic setting}

Along this coast, tides are semi-diurnal and macro-tidal, with a mean spring tidal range of 6 m; tidal currents flow southward during the flood and northward during the ebb (Table 1). The dominant incident wave approach is from the north to east quadrant (corresponding to the longest wind fetch). Offshore significant wave conditions are characterized by a $50 \%$ exceedence significant wave height of $0.5 \mathrm{~m}$ and a modal wave period of $4 \mathrm{~s}$, but wave heights can reach $2.5 \mathrm{~m}$ in winter (van Houwelingen et al., 2008). Wave-driven processes and flood residual tidal currents are the main drivers of alongshore sediment transport which is directed towards the south (Pye, 1995; van Houwelingen et al., 2006). Storm surges are relatively rare, but the most severe recent events occurred in 1953 (Barnes and King, 1953; Brampton and Beven, 1987) and in 1978, and significantly affected the Lincolnshire coast (Steers et al., 1979; Blott and Pye, 2004). Severe storm surges are the result of combined high tidal level and energetic wave activity, caused by deep depressions tracking eastward toward the North Sea and moving around the North Sea basin in an anticlockwise circulation (Dolata et al., 1983). Consequently, surge levels increase southwards along the east coast of England caused by the funnelling effect of the narrowing North Sea. Winds prevail from the southwest (i.e. offshore) and wind speeds are modest $\left(<8 \mathrm{~m} \cdot \mathrm{s}^{-1}\right)$ for the majority of the time (73\%). During winter months, however, the development of high pressure systems over the British Isles and the North Sea can lead to prolonged strong northwesterly and easterly winds (Steers, 1966).

\section{$<$ Table 1>}


179 Global average sea level rose at approximately $1.8 \mathrm{~mm}$ year $^{-1}$ between 1961 and 2003, but 180 has accelerated to $3.1 \mathrm{~mm}^{\text {year }}{ }^{-1}$ over recent years (IPCC, 2007). Along the east coast of 181 England, sea-level rise is lower than this global average at c.1 mm year ${ }^{-1}$ (HECAG, 2009, Woodworth et al., 2009). For the purposes of this study sea level is considered to have been negligible from 1850 to 2010.

\section{Methods and Approach}

Changes in coastline position (section 3.2) from the mid-1990s for the whole sediment cell were determined using cross-shore topographic surveys. From these, we identified 6 specific areas of interest (AOIs) within the sediment cell representing a range of coastal geomorphological features (Table 2). These 6 AOls were examined in more detail to determine:

1. the changing position and relative rate of retreat or accretion of the coastline from the mid- to late-1800s to date;

A preliminary exploration of the key environmental factors affecting rates of coastline change was made using climate and tidal data, including the potential for using a proxy dataset to explain long-term geomorphological changes. 


\subsubsection{Topographic and bathymetric profiles}

204 The temporal frequency of cross-shore topographic surveys around the UK is variable and

205 for this study dates were selected that were: a) available for all AOls, b) corresponded to aerial photograph coverage, and c) maximized the length of the record. Surveys were used

207 from the mid-1990s (one of 1994, 1996 or 1997), 1999, 2005, 2008 and 2010 and were supplied for the Holderness coast by the East Riding of Yorkshire Council, and for Lincolnshire by the UK Environment Agency. For each year, a total of 160 profiles, surveyed in summer or early autumn, was analysed (profile spacing $0.5 \mathrm{~km}$ and $1 \mathrm{~km}$ along the East Riding and Lincolnshire coasts, respectively). Initially surveys were conducted using a standard total station (horizontal accuracy $\pm 0.1 \mathrm{~m}$ and vertical accuracy $\pm 0.01 \mathrm{~m}$ ) located over Ordnance Survey (OS) control points and referenced to the ODN datum. However, since 1999 and 2003 (East Riding and Lincolnshire, respectively), surveys have been made using a RTK-GPS system. Detailed topographic airborne laser surveys have been undertaken along the East Riding coast since 2008 (horizontal accuracy $\pm 1 \mathrm{~m}$; vertical accuracy $\pm 0.15 \mathrm{~m}$ ). From these we extracted cross-shore topographic profiles along the same lines used in earlier surveys.

Nearshore changes were determined using bathymetric surveys made as seaward extensions of the terrestrial cross-shore topographic profiles, and carried out by Gardline under contract to the UK Environment Agency in 1999, 2005 and 2008 along the Lincolnshire coast only. The surveys employed single multi-beam echo-sounders, the accuracy of which has been estimated to be $\pm 1 \mathrm{~m}$ in the horizontal and $\pm 0.005 \mathrm{~m}$ in the vertical (Gardline, 2008). 
For each AOI, coastline change was estimated over a $\sim 150$-year period using historic OS maps (1854-1951: Table 3) and aerial photographs (1953-2010: Table 3 - available data vary by site). Analysis of the historical OS maps can often experience a delay between field survey dates and the publication dates, so that it is difficult to establish specifically when surveys were undertaken. Aerial survey acquisitions were generally during summer months. The use of historical data and combining different data sources can be subject to uncertainties and errors (Thomas et al., 2011; James et al., 2012) which were minimized where possible. Aerial photographs were individually registered against the 2010 orthorectified photographs using the British National Grid (OSGB36) reference system, and ArcMap 9.3 software. Registration was based upon eight stable ground control points (e.g. buildings, road junctions) visually identifiable on all photographs; an average error of $\pm 1.5 \mathrm{~m}$ is considered acceptable (Dolan et al., 1991; Chaverot et al., 2008). The root mean square error (RMSE; Maune, 2007) associated with the geo-referencing process was less than 3.5 $\mathrm{m}$ for each aerial photograph. Independent error estimates were also undertaken by measuring the positional difference of six additional ground control points, on every map and aerial photograph and the same features on the 2010 ortho-rectified photograph. The average difference for the OS maps ranges between $6.6 \mathrm{~m}$ and $7.3 \mathrm{~m}$, while the errors of ortho-photographs are estimated to be $3.4 \mathrm{~m}$ in 1953, and below $2 \mathrm{~m}$ for all others and deemed to be within acceptable limits (Longley et al., 2005).

$<$ Table 3>

The coastline (section 3.2) on each map and aerial photograph was digitized using ArcView 9.3 software. The Digital Shoreline Analysis System (DSAS) enables calculation of rate of change statistics from multiple shoreline positions (Thieler et al., 2009; Brooks and Spencer, 2010;) and was used in combination with ArcView to calculate coastline change between consecutive maps and aerial photographs. For this study, transects were generated every $100 \mathrm{~m}$ perpendicular to the reference coastline, defined as 1854 and 1891 for the East 
256 Riding and Lincolnshire coast AOls respectively (Table 2). At Saltfleetby, the number of

257 transects was reduced due to a lack of ground control points in part of the AOI and historical 258 coastal change was only estimated from ortho-photographs. This is because when measured using the above technique there was a difference in the coastline position depicted on the 1951 OS map and that interpreted from the 1953 aerial photographs of 625 $\mathrm{m}$. In the context of other coastline changes, such high rates of accretion are highly unlikely and are attributed to errors and uncertainties in the mapping process (James et al., 2012). Within DSAS, the End Point Rate (EPR) method, determining the distance between the earliest and the most recent coastlines divided by the time between surveys, was used to obtain rates of coastline change. This also reduces the potential problem of image quality over time (Dolan et al., 1991).

\subsection{Definition of morphological parameters}

Defining a consistent reference point along a dynamic coastline is challenging due to variations in tide levels, meteorological or marine conditions (Pajak and Leatherman, 2002; Thieler and Danforth, 1994), and limitations of spatial resolution during data acquisition

272 (Cracknell, 1999). Here, the coastline was defined from the topographic profiles using a fixed reference plane at HAT (highest astronomical tide) level for the sandy beaches along Spurn Head and the Lincolnshire coast; for precision, cross-shore profiles were linearly interpolated to $0.1 \mathrm{~m}$. The HAT level often coincides with the seaward limit of vegetated coastal foredunes and can provide an objective, repeatable way of identifying morphological sub-unit boundaries (Guillén et al., 1999). However, along the East Riding coast the top of cliff/cliff base position identified from field or airborne surveys was assumed to provide a better representation of the coastline (Brooks and Spencer, 2010). Coastline changes were investigated relative to the initial survey if profiles did not reach the HAT level (with first measureable survey being the zero, or reference, line). 
The topographic profiles were also used to quantify sediment budget changes in the AOls (1997-2010 East Riding; 1994-2010 Lincolnshire). Cross-shore profiles were divided into three morphological units - backshore, foreshore and nearshore - and sediment volume was determined using simple trapezoidal area calculations under the survey line for one unit length $\left(\mathrm{m}^{3} \mathrm{~m}^{-1}\right)$ of coastline. The reference base for the backshore was +MHWS (mean high water spring) height (Fig. 2), and thus corresponds to the sediment unit which is only affected by marine processes during energetic events. The boundaries of the foreshore unit are MHWS and ODN heights $(\mathrm{z}=0 \mathrm{~m})$. In both these units volume is calculated above ODN. The nearshore zone was divided using ODN to MLWS (sub-unit 1 ) and from MLWS to $z=-5$ $m$ (sub-unit 2). The baseline of $z=-5 \mathrm{~m}$ was used to compute the sediment volume (Fig. 2).

Although it has been argued that the HAT level gives a good approximation of coastline (Halcrow, 1988; Saye et al., 2005; Pye et al., 2007), it is worth noting that across different data sources (aerial photographs, topographic profiles) there is no significant correlation between the coastline and HAT level positions (Table 4). There are several possible reasons for this; first the coastline derived from aerial photographs corresponds to the crest of the foredune on sandy beaches, while the HAT level often represents the foredune slope-toe, which is likely to be a more dynamic morphologic feature (Ruessink and Jeuken, 2002). Second, the terrestrial and airborne surveys were not carried out simultaneously so some morphological change may have occurred between survey periods. Coastline position is related to the sand volume of the backshore and, unsurprisingly, there is a negative relationship between sand volume in the backshore and in the foreshore. Recent studies elsewhere in the North Sea Basin have suggested that significant quantities of sand can be 
supplied from the nearshore zone to the shoreface during energetic hydrodynamic conditions (Aagaard et al., 2004; Anthony et al., 2006).

$<$ Table 4>

\subsection{Climate and tidal data sources}

Coastline position reflects processes operating at a range of magnitudes and frequencies. It has been demonstrated, for example, that the coastline can recover relatively rapidly following a single storm event, however sequences of storm events can cause major and sustained alterations due to insufficient recovery time (Douglas and Crowell, 2000; Morton and Sallenger, 2003; Stockdon et al., 2007). Detailed examination of the impact of climate and tidal conditions on the coastline would require continuous records of all variables including coastline position. Whilst coastline position data are only available every few years over the long term and every few months more recently, there are higher temporal resolution records of wind and water level and atmospheric conditions. These data can be used to identify the occurrence and frequency of high magnitude events, such as storms, that are likely to have a significant influence on the coastline.

\subsubsection{Modern records}

Wind and water level records were examined from 1994 to 2010 to investigate the causes of temporal and spatial variability in coastline dynamics. Hourly mean wind speed and direction were obtained from Donna Nook weather station and fifteen-minute measurements of the water level at Immingham tide gauge were supplied by the British Meteorological Data Centre and the British Oceanographic Data Centre (BODC) respectively. Data relating to water levels obtained in Chart Datum were converted to Ordnance Datum using the 
conversions at Spurn Head and Skegness given by BODC (www.bodc.ac.uk). Within macro-

334

tidal environments, the primary factor controlling storm impacts is the water level reached during storm surges, and it must be associated with both wind speed and direction, and amplitude of surge (Vasseur and Héquette, 2000). Storm surge impact will only occur during high tides. To identify energetic events with potential impact on the coastline a storm surge was defined as the occurrence of onshore winds (i.e. winds from $350^{\circ}$ to $150^{\circ}$ ) $\geq 14 \mathrm{~m} \mathrm{~s}^{-1}$ combined with a water level $\geq 3.5 \mathrm{~m}$ (ODN). Offshore winds are in the range $180^{\circ}$ to $320^{\circ}$, with all other winds defined as alongshore. The mean of the monthly extreme water levels from 1994 to 2010 was $3.88 \mathrm{~m}$ and $3.74 \mathrm{~m}$ (ODN) at Spurn Head and Skegness, respectively. However, tide gauge measurements do not always reflect the hydrodynamic processes operating near the coast (Masselink and Hughes, 2003; Parker and Foden, 2009), particularly the run-up (set-up and wave up-rush) which can reach tens of centimetres along a macro-tidal beach during a storm surge. Therefore, a threshold of $3.5 \mathrm{~m}$, slightly lower than the mean monthly extreme water level, was selected. This also corresponds approximately to the height of the interface between the foredune toe and the gentle beach slope along the Lincolnshire coast.

\subsubsection{Proxy records of wind strength}

The lack of long, continuous wind records has limited exploration of the impacts of long-term variations in storminess. However, given that the passage of synoptic scale storms is associated with strong winds due to intense pressure gradients (Carnell et al., 1996) it may be possible to use historical records of synoptic conditions to estimate long-term storminess (Alexandersson et al., 2000; Wang et al., 2009; Donat et al., 2010). Studies have suggested that the North Atlantic Oscillation (NAO) may control the occurrence of storm surge in the Atlantic and thus potentially influence coastal morphological changes (Woolf et al., 2002; O'Connor et al., 2011; Thomas et al., 2011). However, no clear associations have been 
found between NAO and the extreme wind and water climate in the North Sea (Woolf et al., 2003; Tsimplis et al., 2005), probably due to the sheltering effect of the British Isles land mass.

A method of classifying the daily circulation patterns of the British Isles $\left(50^{\circ}-60^{\circ} \mathrm{N}, 2^{\circ} \mathrm{E}-\right.$ $10^{\circ} \mathrm{W}$ ) was developed by Lamb (1972) and has been applied to a range of west European climatological and environmental studies (El-Kadi and Smithson, 1992; Wilby et al., 1997; Buchanan et al., 2002). Lamb's subjective classification used daily atmospheric pressure charts to examine the surface airflow pattern and steering of the circulation system. Eight main directional types are recognized as the cardinal points, and there are three main nondirectional types: anticyclonic, cyclonic, and unclassified. Days not characterized by a single weather type can be classified into one of nineteen hybrid combinations of the main types. Jenkinson and Collinson (1977) subsequently designed an objective, automated version of Lamb's classification (Jones et al., 1993) to produce the Jenkinson daily weather type (JWT) catalogue (also known as Circulation Weather Type; CWT). JWT is based on a 16-point grid of mean sea level pressure data over the British Isles to determine numerical values or indices of geostrophic wind total flow (F) and cardinal direction (D) at $0.1^{\circ}$ intervals.

In this study, the Jenkinson daily synoptic indices from 1871 to 2010 were used as a climate proxy (provided by the Climate Research Unit, University of East Anglia, UK). Wind flow expressed in pressure units was converted to $\mathrm{m} \mathrm{s}^{-1}\left(1\right.$ unit $\left.=0.617 \mathrm{~m} \mathrm{~s}^{-1}\right)$ and the JWT was then used to determine the number of days when onshore, offshore, and alongshore winds exceeding $14 \mathrm{~m} \mathrm{~s}^{-1}$ occurred. These records were used to evaluate the annual variability in wind storminess at the synoptic scale. 


\subsubsection{Flamborough Head to Gibraltar Point}

388

<Fig. 3>

On average, the Holderness cliffs retreated $-28 \mathrm{~m}$ between the initial survey (mid-1990s) and 2010 , but changes along this stretch of the coast varied from cliff retreat (erosion) of $-89.8 \mathrm{~m}$ at the P97 profile to an advance (accretion) of $+36.9 \mathrm{~m}$ at the P127 profile near Spurn Head between 1997 and 2010. In the north (P8-9) the coastline is near-stable due to sea defences (Fig. 3: where positive values indicate accretion or seawards extension and negative values indicate retreat or erosion). The mean short-term rate of retreat of the Holderness cliffs is $1.88 \mathrm{~m} \mathrm{year}^{-1}$ but this varied over the survey period from -1.67 m year ${ }^{-1}$ (1990s-2005), followed by more rapid erosion of $-2.65 \mathrm{~m}$ year $^{-1}(2005-2008)$ then slowing to $-1.71 \mathrm{~m}$ year ${ }^{-1}$ (2008-2010). Along Spurn Head, parts of the spit extended seawards (e.g. profile P127 showed accretion of $+37 \mathrm{~m}$ ) and other parts eroded (narrowed). The mean rate of change along Spurn Head varied from $+2.84 \mathrm{~m}_{\text {year }}{ }^{-1}$ at P127 (centre of the spit) to $-3.14 \mathrm{~m}_{\text {year }}{ }^{-1}$ at P131 (south) between 1997 and 2010. 
Along the Lincolnshire coast, coastline change (1994-2010) varied from retreat of $-11.3 \mathrm{~m}$ at

410 the L2A5 profile to an advance of $+191.3 \mathrm{~m}$ at the L2E4 profile due to the extension of the

411 saltmarsh at Saltfleetby (Fig. 3). At Donna Nook the greatest seawards advance was +17.6 m (L1A4) whilst at Theddlethorpe it was $+37.3 \mathrm{~m}$ (L2D1). Further south, changes range from $-2.9 \mathrm{~m}$ at the profile L2B7 to $+54.6 \mathrm{~m}$ at the L2C6 (just north of Skegness) between 1994 and 2010.

\subsubsection{Specific areas of interest - trends in coastline position 1800s-2010}

417 Within the sediment cell, the AOls have very different spatial and temporal dynamics. Over the past 150 years the Easington cliffs have been eroding (Fig. 4). Mean cliff retreat rate is $2 \mathrm{~m}$ year $^{-1}$ but it exceeded $-3 \mathrm{~m}$ year $^{-1}$ for the periods 1854-1890, and 1969-2005. The annual rate of cliff erosion decreased to $-1.36 \mathrm{~m}_{\text {year }}{ }^{-1}$ between 2005 and 2010 . The highest rates of retreat occur along the southern urbanized coastal sections and locally reached -3.9 $\mathrm{m} \mathrm{yr}^{-1}$ from 2008-2010 and -5.6 $\mathrm{m} \mathrm{yr}^{-1}$ from 1952 to 1969. Over the long-term North Spurn Head is eroding with a mean rate of coastline change of $-1.56 \mathrm{~m}_{\text {year }}^{-1}$ for the period 18542010 (Fig. 4). As at Easington, the highest rate of erosion measured (-4.9 m year $\left.{ }^{-1}\right)$ occurred between 1951 and 1969. Since 1969, data from the aerial photograph analysis indicate that the mean annual rate of retreat is slowing down.

The downdrift sector of the sediment cell (2c - Lincolnshire) is dominated by sandy beaches and saltmarshes (Table 2). At Donna Nook map and aerial photograph analyses indicate a seaward advance of the coastline of $2.7 \mathrm{~m}$ year $^{-1}$ (Fig. 5A). Since 1951 the rate of accretion 
has been relatively constant. This AOI stretches $5.1 \mathrm{~km}$ alongshore but coastline advance since 1891 has varied from $+46 m$ in the north to $+449 m$ at the southern end of the site.

$<$ Fig. 5>

At Saltfleetby, coastline evolution was only investigated between 1994 and 2010 (section 3.1.2). Results indicate erosion of $-1.1 \mathrm{~m}$ year $^{-1}$ between 1994 and 2008 , followed by a more recent phase of accretion (Fig. 5E). The Saltfleetby AOI is characterized by extensive saltmarsh partially bounded on the seaward side by sand dunes. These dunes have been very dynamic and their development appears to be linked to that of the saltmarsh. Aerial photograph analysis indicates both an inland migration and decrease in size of these dunes. Taking the Saltfleetby $\mathrm{AOI}$ as a whole, the overall erosion trend reflects the morphological changes of these coastal dunes. By excluding transects intersecting the dunes, the results indicate that where saltmarsh dominates it is accreting at a rate of $+1.15 \mathrm{~m} \mathrm{year}^{-1}$. A gradual increase in the rate of accretion was also observed from $+1.36 \mathrm{~m} \mathrm{year}^{-1}$ (1999-2005) to $+2.64 \mathrm{~m}$ year $^{-1}(2008-2010)$.

South of Saltfleetby, at the Theddlethorpe AOI there is no saltmarsh, but a wide beach with well-developed dunes. Within the AOI overall coastline position advanced $+126 \mathrm{~m}$ in the north increasing to $\mathrm{c} . .+185 \mathrm{~m}$ in the south. Here the coastline is accreting rapidly at a mean rate of $2 \mathrm{~m}$ year $^{-1}$ (1891-2010). As with the other AOls, the rate of coastline change has varied through time and between 1951 and 1953 an accretion rate as high as $+7.67 \mathrm{~m}_{\text {year }}{ }^{-1}$ is suggested by our analysis; however this may be over-estimated due to the change in data source from the OS map (1951) to aerial photographs (1953). From the photo-interpretation analysis, the rate of accretion varied with a mean annual rate from c. $+3.1 \mathrm{~m}$ year ${ }^{-1}$ for 1976 - 
4581983 to just $+0.97 \mathrm{~m}$ year $^{-1}$ over the period 2005-2008. By considering the photo459 interpretation results only, the mean rate of coastline accretion was of $+1.9 \mathrm{~m}$ year $^{-1}$ between $^{-1}$ $4601953-2010$, which is similar to the average estimated for the 119-year study period.

461

462 No detailed analyses of the coastline changes were undertaken along the Skegness coast because it has been protected by sea defences which were installed following the 1953 floods and are well maintained (HECAG, 2009). Sea defences prevent or alter interactions between inland and tidal zones, however since 1994 the data show accretion seaward of the defences along a vegetated line which has extended both alongshore and towards the sea (Fig. 6). This may be a response to a major sand nourishment programme undertaken just to the north along the beach at the L2B6 profile of $210,000 \mathrm{~m}^{3}$ in 1994 , with subsequent replenishment in 2006 and 2007 (Environment Agency, 2008).

Tables 5 and 6 present the net sediment budget calculated individually for the backshore, foreshore and nearshore (bathymetric) units in each of the AOls (Fig. 2). The data shown are the total gain (+) or loss (-) of sediment in $\mathrm{m}^{3} \times 10^{3}$ between successive surveys, and cumulative change through time. Annual rate of change in $\mathrm{m}^{3}$ year ${ }^{-1}$ is also estimated.

$<$ Table 5> 
482 At Easington, from 1997 to 2010 there was a cumulative sand loss of c. $-66.9 \times 10^{3} \mathrm{~m}^{3}$ for the 483 combined backshore and foreshore units (Table 4). The majority of this is accounted for by 484 cliff erosion in the backshore which is twenty-two times greater than losses from the foreshore unit. North Spurn Head was also affected by overall sand loss with an erosion rate of c. $-1.5 \times 10^{3} \mathrm{~m}^{3}$ year $^{-1}$ although during specific periods both the backshore (1997-1999) and foreshore (1999-2005) did gain sediment (c. $-8.3 \times 10^{3} \mathrm{~m}^{3}$ and $0.8 \times 10^{3} \mathrm{~m}^{3}$ respectively).

As might be expected from the long-term coastline trends described above, the Lincolnshire coast overall gained sediment from 1994-2010. At Donna Nook the results indicate an annual positive budget of $49.9 \times 10^{3} \mathrm{~m}^{3}$ year $^{-1}$. The backshore displayed the greatest mean accretion rate of $30.5 \times 10^{3} \mathrm{~m}^{3}$ year ${ }^{-1}$, however net volume gain has fallen since 2005 with sand losses between 2005 and 2008. Similarly at Saltfleetby there were volumetric gains in both the backshore and foreshore from 1994 to 2005 followed by overall sediment losses from 2005 to 2010 . Overall Theddlethorpe gained on average c. $47.6 \times 10^{3} \mathrm{~m}^{3}$ year $^{-1}$ from 1994 to 2010 but all of the increase in sediment volume was on the backshore (c. $63 . \times 10^{3}$ $\mathrm{m}^{3}$ year ${ }^{-1}$ ) whilst the foreshore actually lost c. $-15.4 \times 10^{3} \mathrm{~m}^{3}$ year ${ }^{-1}$. At Skegness there was a total mean accretion of c. $21.5 \times 10^{3} \mathrm{~m}^{3}$ year-1 with the greatest changes recorded in the backshore unit.

For the nearshore units (Table 5) there were overall sediment gains at Donna Nook and Skegness but sediment losses at Saltfleetby $\left(-6.3 \times 10^{3} \mathrm{~m}^{3}\right.$ year $\left.{ }^{-1}\right)$ and Theddlethorpe ($35.1 \times 10^{3} \mathrm{~m}^{3}$ year $\left.^{-1}\right)$. At Theddlethorpe, interestingly the nearshore sub-unit 1 from ODN to MLWS experienced a significant sand loss, whilst accretion took place in the seaward nearshore unit. At Skegness the nearshore zone gained sediment in sub-unit 1 but lost sediment in sub-unit 2. 
508

509

510

511

512

513

514

515

516

517

518

519

520

521

522

523

524

525

526

527

528

529

530

531

532

4.2 Forcing factors

\subsubsection{Twenty-year record}

Strong onshore winds occurring during astronomical high tides result in storm surges that could be responsible for coastline erosion and retreat. The analysis of forcing factors for the period 1993-2009 shows water levels above $3.5 \mathrm{~m}$ are infrequent and no storm surge events were recorded in 1994-1995 and 2002-2003 (Fig. 7). Although storm surge frequency was variable, the mean rate of coastline retreat at Easington was relatively constant from 19942010. At North Spurn Head storm activity (1-5 events $\mathrm{yr}^{-1}$ ) from 1997-2001 coincided with a phase of accretion (Fig. 7) whilst from 2002-2006 storms were less frequent and this included a phase of coastline erosion of up to $-1.3 \mathrm{~m} \mathrm{yr}^{-1}$.

\section{<Fig. 7>}

Along the Lincolnshire coast, at Donna Nook (Fig. 7C) up to 8 storm surges per year occurred between 1994 and 1998 and this coincided with coastline accretion of c. +4 m year 1. Coastal propagation subsequently continued at a slower but relatively constant rate. A stormy phase from 1996-1998 coincided with saltmarsh retreat at Saltfleetby AOI of $-2.3 \mathrm{~m}$ year $^{-1}$ however this slowed down to less than -0.3 m year $^{-1}$ between 1999 and 2004 before accelerating back to $-2.3 \mathrm{~m}$ year $^{-1}$ from $2005-2007$, another storm phase. However, where it is unconstrained by the coastal dunes, the saltmarsh shows significant seaward advance over the last twelve years, with no clear relationships with the occurrence of storm surge events. At Theddlethorpe the highest rates of coastline accretion $\left(+2.5 \mathrm{~m}\right.$ year $\left.{ }^{-1}\right)$ occurred between 1994 and 1998 (Fig. 6E) when up to 8 storms per year were recorded. The rapid coastline advance continued in the absence of frequent storm events between 1999 and 2004 and continued, but at a slower rate until 2010. This decrease in the rate of advance 
533

534

535

536

537

538

539

540

541

542

543

544

545

546

547

548

549

550

551

552

553

554

555

556

coincided with a period of slightly higher storm surge activity. At Skegness from 1999-2004 the coastline (HAT level) prograded at a rate of $+1 \mathrm{~m}^{\text {year }}{ }^{-1}$ but changed to a retreat of $-2 \mathrm{~m}$ year $^{-1}$ between 2008 and 2010, possibly in response to storms in 2008.

\subsubsection{Long-term record}

Fig. 8 shows the occurrence of days with high wind speeds (storms) from 1871 to 2010 over the British Isles indicated by JWT. The most frequent winds are offshore, coinciding with strong westerly winds in winter. The long-term trend of strong offshore winds appears relatively stable although with a slight fall in frequency in the 1960s. However, offshore winds are not likely to be associated with significant storm surges. Rather storm surge will be associated with strong onshore winds. From 1871-2010 the annual frequency of onshore winds $\geq 14 \mathrm{~m} \mathrm{~s}^{-1}$ varies from zero in 1932 to 19 in 1917 . The 5-year running mean indicates three peaks in the onshore storm event record in 1876, 1878, and 1883 . This last peak was followed by a relatively stable period of 35 years. Three distinct stormy periods occurred in 1955-1970, 1975-1988 and 1994-2000 (Fig. 8). Strong alongshore winds typically occur on fewer than 6 days per year.

<Fig. 8>

To assess the utility of the Jenkinson weather catalogue as a proxy for storm surge, a correlation analysis was undertaken between the frequency of storm surges predicted per year using recorded wind and tide data from 1994 to 2010 and the incidence of onshore wind events exceeding $14 \mathrm{~m} \mathrm{~s}^{-1}$ predicted by JWT records for the same period. The temporal patterns of storm frequency are broadly similar (Fig. 9) and high correlation coefficients are 
557 obtained for both Skegness $(r=0.52, p<0.05)$ and Spurn Head $(r=0.58 p<0.05)$ suggesting

558 the Jenkinson weather catalogue may be a useful proxy for long-term storminess.

559

560

$<$ Fig. 9>

561

562

\section{Discussion}

An examination of detailed records over the past two decades and longer historical records demonstrates clear trends in erosion and accretion along the Flamborough Head to Gibraltar Point coast. These trends can be ascribed to factors such as natural antecedent conditions, relative position within the sediment cell (i.e. updrift/downdrift) and human activities. In this discussion, we consider the short-term changes in coastline position and sediment budget and their relationships with environmental forcing factors, the long term historical coastline changes and finally possible response of the coastline to sea level rise.

\subsection{Coastline changes from mid 1990s-2010} Unsurprisingly, the topographic profile data indicate rapid and significant erosion of the Holderness cliffs since the mid-1990s. Spatially-averaged retreat rates suggest more rapid erosion from 2005-2008 (>2.6 $\mathrm{m} \mathrm{yr}^{-1}$ ) compared with preceding and following years (c. $1.7 \mathrm{~m}$

$575 \mathrm{yr}^{-1}$ ). However, rates of cliffline recession are spatially very variable (Fig. 3). This reflects

576 localised occurrence of landslips, which typically cause a few years of increased recession

577 followed by a period of below average retreat (Pringle, 1985; Posford Duvivier, 1992), such as described for profiles P78 and P95 by Quinn et al. (2009), the location of intertidal sandbars which accelerate cliff erosion rates (Pringle, 1985; Pethick, 1996; Moore et al., 1998) and the presence or absence of offshore sand banks which reduce inshore wave 
581

582

583

584

585

586

587

588

589

590

591

592

593

594

595

596

597

598

599

600

601

602

603

604

605

606

energy and hence slow retreat rates (Eurosion, 2003). Changes in the HAT level indicate that, downdrift of Holderness, the north Lincolnshire beaches are accreting. Leggett et al. (1998) also documented accreting beach profiles along the north Lincolnshire coast with a positive change of 2\% (by volume) from 1991-1996. Between Mablethorpe and Skegness, the coastline has been affected by beach nourishment since 1994, and overall the HAT level has undergone seaward extension. The UK Environment Agency (2011) suggests accretion of the upper-beach in this location can be attributed to retention of renourishment material blown up the beach.

Using topographic profiles for all the cliffed sections of the East Riding coast, we calculated that the retreating cliffs have lost $1,004,755 \mathrm{~m}^{3} \mathrm{yr}^{-1}\left(1000 \times 10^{3} \mathrm{~m}^{3} \mathrm{yr}^{-1}\right)$ of sediment since the initial survey in the mid-1990s. This rate is comparable to the estimate of $1000 \times 10^{3} \mathrm{~m}^{3}$ year $^{-1}$ (from 1852-1952) by Valentin (1971). ABP (1996) predicted a slightly higher cliff erosion rate of up to $1400 \times 10^{3} \mathrm{~m}^{3}$ year ${ }^{-1}$. The combined sediment losses from both the cliffs and the shoreface along the Holderness coast are estimated to be in the region $2500-3000 \times 10^{3} \mathrm{~m}^{3}$ year $^{-1}$ (ABP, 1996; Balson et al., 1996, 1998; Eurosion, 2003), which increases to 3900-4700 $\mathrm{x} 10^{3} \mathrm{~m}^{3}$ year ${ }^{-1}$ if the lower seabed to the limit of erosion is included (Wingfield and Evans, 1998). Of this eroded material $60-80 \%$ is clays and silts, while the rest is predominantly sand and gravels (Balson and Harrison, 1988; Blewett and Huntley, 1998; Townend and Whitehead, 2003). Balson et al. (1998) estimated that $33 \%$ of the sediment is eroded from the cliff, and $67 \%$ from the shorefaces and seabed.

Calculations for the $\mathrm{AOI}$ at Easington for this paper suggest the cliffs here have yielded approximately $66.9 \times 10^{3} \mathrm{~m}^{3}$ year ${ }^{-1}$ (Table 5). Posford Duvivier (1992) modeled the wavedriven littoral drift at Easington (including both sediments being transported from the northern cliffs and input from Easington itself) and predicted a southward longshore sand 
607 transport of $157-310 \times 10^{3} \mathrm{~m}^{3}$ year-1 from this area. Easington marks the point at which the 608 southwards travelling sand derived from erosion along the total length of the cliffs moves 609 offshore (Halcrow and Geosea, 1990), although the precise transport pathways of eroded 610 sediments will depend on their mineralogy and grain size (Newsham et al., 2002). This offshore transport is a result of a combination of the change in both the orientation of the coast and the direction of the tidal currents at this point. Previous studies suggest $3-6 \%$ of the eroded cliff material is transported to the southern end of Holderness and incorporated in to the Spurn Head spit whilst the remainder is deposited in the nearshore and offshore zones (Valentin, 1971; Ciavola, 1997).

Whilst the littoral drift may input $30-60 \times 10^{3} \mathrm{~m}^{3} \mathrm{yr}^{-1}$ to the spit (Valentin, 1971; Ciavola, 1997), our results show that erosion from North Spurn Head has the potential to supply $1.5 \times 10^{3} \mathrm{~m}^{3}$ year $^{-1}$ to areas downdrift (Table 5). The principal pathway of bedload sediment material is southwards towards the nearshore sand banks of The Binks, which act as a sand reservoir for Spurn Head and a buffer to erosion under energetic hydrodynamic conditions. The littoral cell of interest has three sub-cells, the central one ( $2 b$; Fig. 1 ) being defined by the Humber Estuary. The sediment budget of the Humber Estuary is complex but whilst total sediment flux through the estuary mouth is very high, the net exchange between the estuary and the North Sea is low (Townend and Whitehead, 2003) with estimates of sediment input to the North Sea ranging from 100-255 $\mathrm{kt} \mathrm{yr}^{-1}$ (compared with 1400-2610 kt yr $\mathrm{yr}^{-1}$ eroded from Holderness; McCave, 1987; HR Wallingford, 1992). Only around 1\% of the total sediment is estimated to enter and circulate into the Humber estuary before being expelled back in to the North Sea (Halcrow and GeoSea, 1990; Black and Veatch, 2004). Fine sediments eroded from the updrift Holderness cliffs are transported into the estuary by the flood tide and coarser sand-sized materials are moved in to the marine environment (ABP, 2000). Strong tidal flows can prevent gravels and sands from crossing the Humber Estuary (HECAG, 2009), however, Robinson (1968) released seabed drifters from The Binks near Spurn Head, 
$60 \%$ of which were recovered from the south shore confirming a sediment transport pathway across the mouth. Medium and fine sands can be transported across the estuary mouth especially during storm conditions and build up in offshore sand banks at Donna Nook (Steers, 1966; Tonk, 2000; HECAG, 2009). This deposition is reflected in this study through the dominance of accretion in both the back/fore shore and nearshore zones at Donna Nook where the volume of accretion is equivalent to $5.8 \%$ of the total estimated Holderness cliff erosion (Tables 5, 6). Additional sediment supply to this area can come from The Binks during storm surge conditions (HR Wallingford, 2002).

From the mid-1990s to 2010 the back and fore shore units at Saltfleetby and Theddlethorpe have been accreting, while erosion has characterized the nearshore zone (Tables 5, 6). The total annual sediment supply at Saltfleetby and Theddlethorpe is equivalent to $4.7 \%$ of that eroded from the East Riding coast. At Mablethorpe, the coastline switches from accretion to erosion (Schans et al., 2001) driven by a combination of exposure to wave activity (Dugdale and Vere, 1993) and anthropogenic pressures (Robinson, 1964; Pye, 1995). The artificially nourished coastal section from Mablethorpe to Skegness was assumed not to accumulate sediment from the Holderness cliffs. Data from topographic and bathymetric profiles at Gibraltar Point indicate that sediment input has been approximately $181.9 \times 10^{3} \mathrm{~m}^{3}$ year ${ }^{-1}$. Assuming no additional sources, this quantity would represent $18.7 \%$ of the cliff material eroded to the north. Again assuming no additional sediment sources or sinks along the coastline, when combined with the $5.8 \%$ input to Donna Nook and $4.7 \%$ input at SaltfleetbyTheddlethorpe, this suggests that only $29 \%$ of the material eroded in sediment sub-cell $2 a$ is transported 'directly' by the littoral drift to the Lincolnshire coast (sub-cell 2c). The majority of sand material eroded from the Holderness cliffs can therefore be assumed to move offshore, however the division is likely to be less clear-cut as material transported offshore to the Binks and other sand banks along the Lincolnshire coast, will be redistributed by cross-shore 
660

661

662

663

664

665

666

667

668

669

670

671

672

673

674

675

676

677

678

679

680

681

682

683

684

wave currents (Halcrow, 1988; ABP, 1996). Sediments introduced to the system during the nourishment programme may also form some of the inputs to Gibraltar Point.

Over the short-term there were few storm surges where wind speed was $\geq 14 \mathrm{~m} \mathrm{~s}^{-1}$ and water level was $\geq 3.5 \mathrm{~m}$ ODN, but the highest frequencies occurred between 1996-2001. This was followed by two very calm years and then by a period of medium activity between 2004-2010 (Fig. 7). At Easington, retreat rates were remarkably constant whereas they varied far more at North Spurn Head and along the Lincolnshire coast. Our data show a positive correlation between storm surge occurrence and coastline position and between storm surge and sand volume in the backshore, whereas there is a negative relationship with the sand volume in the foreshore (Table 4). However, there are no clear relationships between coastline change and storminess. A limitation of our data set is the relative timing of data acquisition in that it rarely includes the coastline position recorded immediately before or after a storm surge, however it may represent the beach morphology in calm weather conditions, and thus the post-storm recovery state.

\subsection{Coastal evolution from the 1800 s to 2010}

Although coastline changes determined from maps and historical aerial photographs are likely to be less reliable than recent field surveys, they are necessary to determine the longterm evolutionary tendency of the coastline. The changes that have taken place in the northern part of this sediment cell (2a) along the Holderness coast have been the subject of numerous previous studies (e.g. Reid, 1885; Valentin, 1954, 1971; Dosser, 1955; Steers, 1966; Mason and Hansom, 1988; HECAG, 2009; Quinn et al., 2009), and beach development in the far south around Gibraltar Point has also received some attention (e.g. King, 1964, 1968, 1973; Barnes and King 1955; King and Barnes, 1964). There has, 
685

however, been considerably less research in the south-central sector of the cell along the north Lincolnshire coast.

In the north of the sediment cell, we determined that the southern Holderness cliffs have, on average, been eroding at $2 \mathrm{~m} \mathrm{yr}^{-1}$ since 1854 (Fig. 11). This is in agreement with previous estimates of 1-2 m yr $\mathrm{m}^{-1}$ over 150 years (Valentin, 1954; Mason and Hansom, 1988; Quinn et al., 2009). Some research indicates that towards Flamborough Head, parts of the north of the Holderness coast underwent aggradation from 1852-1952 (Valentin, 1954; Bird, 1984) but analysis of recent topographic profiles (1994-2010) suggest that currently erosion is taking place along the whole cliffed coastline albeit at a much more rapid rate towards the south. Spurn Head has long been recognized as a very dynamic feature undergoing cyclic breaching, destruction and reformation (De Boer, 1964). This paper has reported significant variability in rates of erosion on North Spurn Head ranging from nearly $-5 \mathrm{~m} \mathrm{yr}^{-1}$ (1951-1969) to $<-0.7 \mathrm{~m} \mathrm{yr}^{-1}$ (1890-1951 2005-2010). This most recent decrease in rates of erosion was also observed by Saye et al. (2005).

In contrast, the beaches of north Lincolnshire have undergone accretion up to $+2.7 \mathrm{~m}$ year $^{-1}$ over the past 120 years (Fig. 11). The result agrees with the study by Halcrow (1988) which indicated accretion from the late $19^{\text {th }}$ century to 1970 . Robinson (1984) also reported that by the early $19^{\text {th }}$ century the Saltfleetby-Theddlethorpe coastline was characterized by an accreting coastline. One of the sediment sources for these beaches is, as mentioned above, material eroded from the Holderness coast (Steers, 1946), but in addition there is onshore movement of material from sand banks (Halcrow, 1988; ABP, 1996; HR Wallingford, 2002). Our analysis did not indicate any general coastline retreat caused by the severe $31^{\text {st }}$ January- $1^{\text {st }}$ February 1953 North Sea storm surge, however the intervals between maps and aerial photographs probably hides some short-term coastline recession. The storm surge impacts in 1953 are also likely to have been reduced by the presence of coastal dunes and 
712 the higher, wide beach along the North Lincolnshire coast (Robinson, 1953; Brampton and 713 Beven, 1987).

714

<Fig. 11>

716

717

5.3 Proxies for storminess

718

Pressure-based circulation weather types, such as the JWT used here, have been widely used to examine general trends and variability in long-term storminess in Europe (e.g. Alexandersson et al., 2000; Donat et al., 2011; Wang et al., 2011) and are generally more reliable proxies over sea than over land (Krueger et al., 2012). We suggest JWT may provide a reasonable proxy for storminess on the east coast of England. Frequencies of storm events identified using JWT data are much higher than those of measured storm surges (Fig. 9); this is because we have not differentiated onshore energetic events associated with high tides, where storm surges would be likely, from those associated with

727 low tides where little or no impact would be expected due to the lower overall water level (Chaverot et al., 2008). Accounting for water level over the longer term is something that could be explored in future. Over long time periods other studies have successfully used similar proxy measures of storminess, such as variations in the NAO, to explain temporal patterns of coastline evolution (Vespremeanu-Stroe et al., 2007; Thomas et al., 2011;

732 O'Connor et al., 2011) which suggests analysis of the JWT data set may be worth pursuing 733 further. 
Overall temporal patterns of storminess (all directional sectors) in the NE Atlantic and North Sea since the 1870s determined using the JWT/CWT approach have shown variable, but typically low, levels of storminess in the late nineteenth century and first half of the twentieth century (Alexandersson et al., 2000; Wang et al., 2009) although in the central North Sea $\left(55^{\circ} \mathrm{N} 5^{\circ} \mathrm{E}\right)$ total gale days indicate high storminess in the early twentieth century (Donat et al., 2011). Minimum storm activity has been put at around 1960 with maximum storminess during the 1990s followed by a decline to long-term average conditions in the early 2000 s (Wang et al., 2009; Donat et al., 2011). This is broadly in accordance with patterns determined in this paper, however due to the geomorphological research questions being addressed we deconstructed the total record into specific directional sectors (onshore, offshore and alongshore) and events meeting specific wind speed conditions, and these components show some differences to the overall pattern. For example, the frequency of JWT onshore wind storms was variable from 1871 to the 1920 s (1-19 events per year), but was slightly higher than the long term mean of 7 events per year. This was followed by a relatively calm period of up to 35 years (Fig. 10A). Peak periods of onshore wind storm events occurred during 1955-1970, 1975-1988, and from the mid-1990s to 2000 . The first of these peak periods contrasts with more widely-observed low levels of overall storminess (which can be seen in the offshore record in Fig. 8). These peaks indicate an increase in wind speeds likely to generate greater significant wave heights and these energetic periods are broadly coincident with the highest rates of coastal erosion recorded between 1854-1890 and 1951-1969 at Easington and North Spurn Head (Fig. 10). The JWT storm event frequency decreased after 2005, which coincides with a decrease of coastline recession rates at these sites. Within a littoral sediment cell with a defined sediment budget, erosion of material in one part of the cell should lead to accretion elsewhere within the cell; accordingly high recession rates along the Easington cliffs between 1891-1910 and 1976-1983 were concomitant with the highest rates of coastline accretion recorded at Donna Nook (18911910) and Theddlethorpe (1976-1983), and from 1994-2005 at both sites (Fig. 10). In contrast, the recent decrease in cliff retreat from 2005-2010 may be the cause of the lower 
rates of seaward accretion along the North Lincolnshire sandy beaches over the same period. In the study region our long-term data set only provides reliable information concerning longshore coastal changes, however, as discussed in section 5.1, the short-term (decadal) data indicate cross-shore sediment transport to and from offshore stores such as sand banks is substantial. As with other regions, such as the Columbia River Littoral Cell (Ruggiero et al., 2005), lack of cross-shore transport data makes it difficult to make longterm sediment budget calculations.

Within our data, one particular period of interest is that between the 1900 s and 1951 where rates of coastline change throughout the sediment cell were very low. This broadly coincides with a long period of low frequencies of annual wind storms (1920-1955). Both the geomorphological and climatological records suggest there was a period of quiescence lasting $\sim 35$ years in the first half of the $20^{\text {th }}$ century. Previous research has identified strong correlations between storminess in the NE Atlantic (including the North Sea) and NAO (e.g. Wang et al., 2009), but in the methods we indicated that winter NAO was not a good indicator of storminess on the east coast of England. Positive winter NAO phase leads to enhanced westerlies due to a stronger than usual sub-tropical high pressure centre and a deeper than normal Icelandic low (Hurrel, 1995) and most storms identified using CWT are associated with westerly flow (Donat et al., 2010). Between 1900s and 1950, winter NAO phase was positive with consecutive strong positive phases between 1900-1915 and 19151930 (Fig. 10B). Over this period, the occurrence of storm events, affecting the North Atlantic west-facing coast would be expected to have increased, whereas the east coasts would be relatively sheltered. It can be suggested, therefore, that although positive NAO phase may not indicate storminess on the east coast of England, it could provide a useful proxy for quiescence. The advantage of using JWT/CWT data sets is that they can be focused on specific directional sectors (in this case winds from the north and the eastern sector (N, NE, E, SE) which is important in the context of understanding the impact of events 
on the coastline. Although the JWT approach was originally developed for the British Isles (Lamb, 1972) it has been successfully applied to other regions including the Netherlands (Buishandt and Brandsma, 1997), Spain (Goodess and Palutikof, 1998, Lorenzo et al., 2008), Portugal (Trigo and Dacamara, 2000) and Morocco (Born et al., 2010) in research focusing primarily on precipitation and catchment scale flooding. This paper, and other recent studies using circulation weather types to examine wind storms (e.g. Wang et al. 2009; Donat et al., 2011), suggest that they could provide a valuable data source for interpreting long-term coastal geomorphological change throughout northwest Europe.

The use of JWT/CWT data merits further exploration but low levels of storminess are not likely to explain fully the relatively static nature of the coastline from 1900 to 1950 . Other possibilities are a redistribution of sediments, for example there was a natural extension of a barrier located seaward of the centre of the Spurn spit during the $18^{\text {th }}$ and $19^{\text {th }}$ centuries (Halcrow, 2002) which may have lead to a reduction in sand volume reaching beaches in north Lincolnshire as the barrier extended (Pye and Blott, 2010). In addition, this coast has a long history of defence. Hard coastal defences were built on sections of the Holderness coast such as Hornsea, Mappleton, Withernsea and Easington in the late $19^{\text {th }}$ century and may have temporarily reduced or stopped the cliff retreat; the construction of a groyne field is also likely to have impeded the littoral drift of sediment (Pye and Blott, 2010). In 1883/84, further groynes and timber revetments were built to prevent breaching and erosion along Spurn Head. Spurn Head was a military stronghold during the second world war and coastal defences were built along the seaward side (De Boer, 1981), which are likely to have reduced alongshore sand transport to the south. These were abandoned and fell in to disrepair in the 1960s.

\subsection{Response of the coastline to sea-level rise}


817 There are number of challenges associated with predicting the response of sediment cell

818 and landform dynamics to climate change and sea-level rise. One of the most important is

819 obtaining historical records over sufficiently long time periods for accurate change detection,

820 particularly given that in many littoral cells short-term changes can occur at a very different

821 rate, or even show the opposite trend, to long-term change (Ruggiero et al., 2005; Brooks

822 and Spencer, 2012). In addition, as demonstrated here, because both cliff and beach systems can exhibit considerable alongshore variability in rates of change, and because sediment processes acting over a larger area can influence local scale change, the spatial scale needs to extend over at least the sub-cell and ideally the whole coastal cell (Ruggiero et al., 2005; Neill et al., 2008; Quinn et al., 2009). In this study, the time interval between data sets (years to decades) and the length of time between the earliest and the most recent data set ( $>110$ years) means the impact of short-term change is minimised; there are clear directional changes at most of the AOIs examined (with the exception of Spurn Head). Over the historical period coastline dynamics in the downdrift sector of the sediment cell (2c) have been controlled by the supply of sand material from the updrift section of the cell (2a), the eroding Holderness coast. During periods of more rapid cliff retreat, rates of coastline progradation have been higher on the Lincolnshire coast; when cliff retreat is slowed, such as during the early twentieth century, rates of accretion downdrift are reduced. For the central sub-cell (2b) historical data used to reconstruct changes in the volume of the Humber estuary since 1851 suggest an overall period of infilling prior to 1940 followed by erosion up to 2000 (although data sources prior to 1936 were incomplete) however there has been no significant change in average flow rates over the last century (Townend et al., 2007).

A number of studies has examined and modelled the likely response of other sectors of the east coast of England (notably sediment cell 3; East Anglia) to future environmental change

842 (Dickson et al., 2007; Dawson et al., 2009; Brooks and Spencer, 2012). Sea level is predicted to rise at an accelerated rate in future (IPCC, 2007) and there is a range of 
possible responses of cliffs to sea-level rise varying from increased retreat rate to decreased retreat rate or no change (Ashton et al., 2011), but sea-level rise is not the only controlling factor on cliff retreat (e.g. Lim et al., 2010). Storm frequency and magnitude are also predicted to increase and will probably heighten coastal erosion as well as flooding on lowlying coasts (Webster et al., 2005; Bindoff et al., 2007; Chini et al., 2010). Dickson et al. (2007) and Brooks and Spencer (2012) used historical data for retreating sectors of the East Anglian coast (Norfolk and Suffolk respectively; both sediment cell 3) to test models for predicting coastline response to sea level rise. Brooks and Spencer (2012) found that the longer the time period for which historical (baseline) data were available, the better the predictions, but importantly found that a single spatially-averaged estimate of retreat performed poorly because the alongshore variation in retreat rates was not accounted for. On the Norfolk coast, models of historical change captured the measured patterns of erosion in the cliffed sectors (e.g. from Weybourne to Eccles) and deposition along the unconsolidated coastline from Eccles to Winterton Ness, and a similar pattern of cliff recession and beach volume increase is predicted under a variety of sea level change and management scenarios (Dickson et al., 2007). In sediment cell 2, it could be assumed that the future rate of cliff erosion and sediment supply will be similar to present day rates (Newsham et al., 2002; Black and Veatch, 2004), although whilst this may be an appropriate assumption at Easington where rates of erosion have been relatively stable for 150 years, at sites such as Spurn Head future behaviour is likely to be harder to predict (Scott and Wilson, 2009). Spurn Head above the upper-intertidal zone is expected to migrate westward, but it is unlikely to extend further south due to the forcing effects of tidal flows and overwashing events that occur during storm surges (East Riding Council, 2004). Models applied to cell 3 suggest that broad spatial patterns of erosion and retreat are likely to continue over the twenty-first century and, similarly; in cell 2 sand eroded from the Holderness cliffs is likely to continue to supply the North Lincolnshire coastline causing ongoing accretion. At present, whilst the Holderness coast has some coastal defences these are insufficient to prevent cliff erosion and the current Shoreline Management Plan recommends letting natural processes 
872 continue except in localised areas where town frontages and infrastructure require protection

873 (HECAG, 2009). Similarly, along the Lincolnshire coast defences are minimal north of

874 Mablethorpe and continued coastal progradation will likely allow this to continue during the

875 current century even under predicted sea-level rise. A largely unknown factor, and one for

876 which there are fewer long-term historical records from which to make predictions, is the

877 impact of cross-shore sediment transport to and from the offshore sand banks. As indicated

878 in section 5.1 offshore sediment transport is substantial and the offshore sand banks play an

879 important role not only in supplying sand to the coastline, but also in reducing wave energy

880 (Steers, 1966; Motyka and Brampton, 1993; Blott and Pye, 2004, Brooks and Spencer,

881 2012) which may impact both coastline recession and progradation rates.

\section{Conclusions}

Spatial and temporal variability in coastline position, rate of change and sediment budget were assessed within a single sediment cell. There have been clear trends in erosion and accretion from Flamborough Head to Gibraltar Point over the past 150 years and the different parts of the sediment cell are clearly connected. High rates of erosion updrift (2a) are associated with high rates of accretion downdrift (2c) and periods of relative stability in these two sections of the sediment cell are broadly coincident. The volume of sediment incorporated in to the accreting beaches represents around $29 \%$ of that eroded from the Holderness cliffs. The results highlight the importance of understanding the variable dynamics of different types of landform occurring within a single sediment cell (e.g. cliffs, dune-backed beaches). Erosion on sandy beaches is often an outcome of storm surges, however where the storm causes the release of large quantities of sediment updrift within the sediment cell, this erosion may be mitigated or, in the case of north Lincolnshire, result in accretion due to the increased sediment supply to areas downdrift. 
898 Overall temporal patterns of storminess in the north Atlantic and North Sea can be identified 899 using pressure-based continental weather types. An exploration of the use of the Jenkinson 900 Daily Weather Type as a proxy for storm surges over the historical record suggests that by 901 deconstructing the data into specific directional sectors, to account for onshore-, offshore902 and alongshore-directed events, useful information on long-term patterns of storminess and 903 its potential impacts on specific coasts can be obtained. The performance of such weather 904 type data for predicting the geomorphological impacts of storm surges would probably be 905 improved by incorporating information about water level with the wind record.

906

907

908 
910 This research was funded by The Crown Estate in association with The National Maritime

911 Museum under a Caird-Crown Estate Research Fellowship awarded to A. Montreuil in 2010.

912 The authors also would like to thank following organizations and individuals for providing

913 aerial photograph, field profile data: David Welsh of the Environment Agency, Neil Mclachlan

914 of the East Riding Yorkshire Council. Historical aerial photographs were supplied by Roger

915 Briggs of Natural England, and the English Heritage of National Monument record.

916 Jenkinson weather catalogue was provided by the Climatic Research Unit of the UEA, and

917 Dr Harpham is thanked for his exceptionally efficiency.

918

919 
921 Aagaard, T., Nielsen, J., Gro Jensen, S., Friderichsen, J., 2004. Longshore sediment 922 transport and coastal erosion at Skallingen, Denmark. Danish Journal of Geography 104, 592314.

ABP, 1996. Southern North Sea Sediment Transport Study, Literature review and conceptual sediment transport model. Report R546, ABP Research and Consultancy Ltd, Southampton.

927 Alexandersson, H., Tuomenvirta, H., Schmith, T., Iden, K. 2000. Trends of storms in NW 928 Europe derived from an updated pressure data set. Climate Research 14, 71-73. Anthony, E.J., Ruz, M.H., Vanhée, S., 2006. Morphodynamics of intertidal bars on a megatidal beach, Merlimont, northern France. Marine Geology 208, 73-100.

Ashton, A.D., Walkden, M.J.A., Dickson, M.E. 2011. Equilibrium responses of cliffed coasts to changes in the rate of sea level rise. Marine Geology 284, 217-229.

Balson, P.S., Tragheim, D., Newsham, R., 1998. Determination and prediction of sediment yields from recession of the Holderness coast, eastern England. Proceedings of the $33^{\text {rd }}$ MAFF Conference River and Coastal Engineers, London, pp. 4.5.1-4.6.2.

Balson, P.S., Tragheim,D., Newsham, R., 1996. A photographic technique to determine the potential sediment yield from recession of the Holderness coast, UK, in Taussik, J., Mitchell, J. (Eds.) Partnership in Coastal Zone Management. Samara Publishing Ltd, Cardigan, pp. 507-514.

940 Balson, P.S., Harrison, D.J., 1988. Marine aggregate survey Phase 1: Southern North Sea, 941 British Geological Survey, Marine report 86/38.

942 Barnes, F.A., King, C.A.M., 1953. The storm flood of $1^{\text {st }}$ February, $1953 \mathrm{II}$, The Lincolnshire 943 coastline and the 1953 storm flood. Geography 38, 141-160.

944 Barnes, F.A., King, C.A.M., 1955. Beach changes in Lincolnshire since the 1953 storm surge. East Midland Geographer 1, 18-28.

Bindoff, N.L., Willebrand, J., 2007. Observations: Oceanic Climate Change and Sea Level. in: Solomon, S., D. Qin, M. Manning, Z. Chen, M. Marquis, K.B. Averyt, M. Tignor and H.L. Miller. (Eds.), Climate Change 2007: The Physical Science Basis. Contribution of Working

949 Group I to the Fourth Assessment Report of the Intergovernmental Panel on Climate 950 Change. Cambridge University Press, pp. 387-429. 
Black and Veatch Ltd., 2004. Humber Estuary Shoreline management plan phase 2, summary of geomorphology studies. Report produced for Environment Agency.

Blewett, J., Huntley, D. 1998. Measurement of suspended sediment transport processes in shallow water off the Holderness coast, UK. Marine Pollution Bulletin 37, 134-143.

Blott, S.J., Pye, K., 2004. Morphological and sedimentological changes on an artificially nourished beach, Lincolnshire, UK. Journal of Coastal Research 20, 241-233.

Born, K., Fink, A.H., Knippertz, P. 2010. Meteorological processes influencing the weather and climate of Morocco. In: Speth, P., M. Christoph, B. Diekkruger, M. Bollig, A.H. Fink, H. Goldbach, T. Heckelei, T., G. Menz, B. Reichert, M. Rossler (eds). Impacts of Global Change on the Hydrological Cycle in West and Northwest Africa. Springer, Berlin, 150-163.

Bowen, A.J., Inman, D.L., 1966. Budget of littoral sands in the vicinity of Point Arguello, California. Coastal Engineering Research Centre. Technical Memorandum 19, 41 pp.

Brampton, A.H., Beven, S.M., 1987. Beach changes along the coast of Lincolnshire, U.K (1959-1985). Proceedings on Coastal Sediments 87. Am. Society of Civil Engineers, 539554.

Brooks, S.M., Spencer, T., 2010 Temporal and spatial variations in recession rates and sediment release from soft rock cliffs, Suffolk coast, UK. Geomorphology 124, 26-41.

Brooks, S.M., Spencer, T. 2012. Shoreline retreat and sediment release to accelerating sea level rise: measuring and modeling cliffline dynamics on the Suffolk Coast, UK. Global and Planetary Change 80-81, 165-179.

Bryant, E.A., 1988. Storminess and high tides beach change, Stanwell Park, Australia, 19431978. Marine Geology 79, 171-187.

974 Buchanan, C.M., Beverland, I.J., Heal, M.R., 2002. The influence of weather-type and longrange transport on airborne particle concentrations in Edinburgh, UK. Atmospheric environment 36, 5343-5354.

977 Buishand, A., Brandsma, T. 1997. Comparison of circulation classification schemes for 978 predicting temperature and precipitation in the Netherlands. International Journal of 979 Climatology 17, 875-889. 
980 Carnell, R.E., Senior, C.A., Mitchell, J.F.B., 1996. An assessment of measures of 981 storminess: simulated changes in northern hemisphere winter due to increasing CO2. 982 Climate Dynamics 12, 467-476.

983 Chaverot, S. Héquette, A., Cohen, O., 2008. Changes in storminesss and shorline evolution 984 along the northern coast of France during the second half of the $20^{\text {th }}$ century. Zeitschrift fuer 985 Geomorphologie 52, 1-20.

986 Chini, N., Stansby, P., Leake, J., Wolf, J., Roberts-Jones, J., Lowe, J. 2010. The impact of 987 sea level rise and climate change on inshore wave climate: a case study for East Anglia 988 (UK). Coastal Engineering 57, 973-984.

989

Ciavola, P., 1997. Coastal dynamics and impact of coastal protection works on the Spurn 990 Head spit (UK). Catena 30, 369-389.

Cooper, J.A.G., McKenna, J., Jackson, D.W.T, O’Connor, M., 2007. Mesoscale coastal 992 behavior related to morphological self-adjustment. Geology 35, 187-190.

Cooper, N.J., Hooke, J.M., Bray, M.J. 2001. Predicting coastal evolution using a sediment budget approach: a case study from southern England. Ocean and Coastal Management 44, 995 711-728.

996

Cooper, N.J., Pontee, N.I., 2006. Appraisal and evolution of the littoral 'sediment cell' 997 concept in applied coastal management: experiences from England and Wales. Ocean and Coastal Management 49, 498-510.

999 Cracknell, A.P., 1999. Remote sensing techniques in estuaries and coastal zones an update. 1000 International Journal of Remote Sensing 19, 485-496.

1001 Dawson, R.J., Dickson, M.E., Nicholls, R.J., Hall, J.W., Walkden, M.J.A., Stansby, P.K., 1002 Mokrech, M., Richards, J., Zhou, J., Milligan, J., Jordan, A., Pearson, S., Rees, J., Bates, 1003 P.D., Koukoulas, S., Watkinson, A.R. 2009. Integrated analysis of risks of coastal flooding 1004 and cliff erosion under scenarios of long term change. Climatic Change, 95, 249-288.

De Boer, G., 1964. Spurn head, its history and evolution. Transactions of the Institute of 1006 British Geographers 34, 71-89.

1007 De Boer, G., 1981. Spurn Point since 1849, in: Neale, J., Flenley, J. (Eds.), The Quaternary 1008 in Britain. Pergamon Press, Oxford, pp. 206-215.

DEFRA, 2006. Shoreline management plan guidance Volume 1: aims and requirements, 44 pp. 
1011 Dickson, M.E., Walkden, M.J.A., Hall, J.W. 2007. Systemic impacts of climate change on an 1012 eroding coastal region over the twenty-first century. Climatic Change 84, 141-166.

1013 Dolan, R., Fester, M.S., Holme, S.J., 1991. Temporal analysis of shoreline recession and accretion. Journal of Coastal Research 7, 723-744.

Dolata, L.F., Roeckner, E., Behr, H., 1983. Prognostic storm surge simulation with a combined meteorological/oceanographic model. North Sea Dynamics, in: Sündermann, J., Lenz, W. (Eds.), North Sea Dynamics. Springer-Verlag, pp. 266-278.

Donat, M.G., Leckebusch, G.C., Pinto, J.G., Ulbrich, U. 2010. Examination of wind storms over Central Europe with respect to circulation weather types and NAO phases. International Journal of Climatology 30, 1289-1300.

Donat, M.G., Renggli, D., Wild, S., Alexander, L.V., Leckebusch, G.C., Ulbrich, U. 2011. 1022 Reanalysis suggests long-term upward trends in European storminess since 1871. 1023 Geophysical Research Letters 38, L14703.

Dossor, J., 1955. The coast of Holderness: the problem of erosion, Proceedings of the Yorkshire Geological Society 30, 133-145.

Douglas, B. C., Crowell, M., 2000. Long-Term Shoreline Position Prediction and Error Propagation'. Journal of Coastal Research 16, 145-152.

Dugdale, R. E., Vere, A., 1993. Saving Lincolnshire's beaches. East Midland Geographer 16, 31-32.

Dugdale, R.E., 1980. Nearshore sandbanks and foreshore accretion on the south Lincolnshire coast. East Midland Geographer 7, 49-63.

East Riding Council, 2004 Coastal processes, pp. 1-4.

El-Kadi, A.K.A., Smithson, P.A., 1992. Atmospheric classifications and synoptic climatology. Progress in Physical Geography 16, 432-455.

1035 Environment Agency, 2004. Lincshore 2005 to 2010 PAR Volume 1, Strategy For Approval. 1036 Report to Environment Agency, Anglian Region, Peterborough. Halcrow, Swindon.

1037 Environment Agency, 2008. Anglian Coastal Monitoring Programme, Coastal Trend 1038 Analysis, Lincolnshire Subcells 2b-c_Grimsby to Gibraltar Point, 63 pp.

1039 Environment Agency, 2011. Anglian coastal monitoring programme, Lincshore coastal 1040 morphology report 2006-2011, 35 pp. 
1041 Eurosion, 2003. Holderness coast, UK, Eurosion case study, DHV group, 22 pp.

1042 Gardline, 2008. Lincolnshire coastline bathymetric/beach survey, summer 2008, survey 1043 report Ref 7689, 19 pp.

1044 Gelfenbaum, G., Kaminsky, G.M. 2010. Large-scale coastal change in the Columbia River 1045 littoral cell : an overview. Marine Geology 273, 1-10.

1046 Goodess, C.M., Palutikof, J.P. 1998. Development of daily rainfall scenarios for southeast 1047 Spain using a circulation-type approach to downscaling. International Journal of Climatology 1048 10, 1051-1083.

1049 Guillén, J., Stive, M.J.F., Capobianco, M., 1999. Shoreline evolution of the Holland coast on 1050 a decadal scale. Earth Surface Processes and Landforms 24, 517-536.

1051 Halcrow and GeoSea Consulting, 1990. The Anglian Sea Defence Management Study 1052 Phase III. Field Survey Report. Volume 3. Estuary Sediment Trends. GeoSea Consulting, 1053 Cambridge.

1054 Halcrow, 1988. The sea defence management study for the Anglian region, study report Sir 1055 William Halcrow \& Partner Ltd, Swindon, UK.

1056 HECAG, 2009. Flamborough Head to Gibraltar Point Shoreline Management Plan, Scott 1057 Wilson, $182 \mathrm{pp}$.

1058 Hooke, J.M., Bray, M.J. 1995. Coastal groups, littoral cells, policies and plans in the UK. 1059 Area 27, 358-368.

1060 Hooke, J.M., Bray, M.J., Carter, D.J. 1996. Sediment transport analysis as a component of 1061 coastal management - a UK example. Environmental Geology 27, 347-357.

1062 HR Wallingford, 1992. Particulate pollutants in the North Sea. Report SR 292. Hydraulics 1063 Research Wallingford.

1064 HR Wallingford, 2002. Southern North Sea Sediment transport Study Phase, Sediment 1065 Transport Report EX 4526, 93 pp.

1066 Hurrel, J.W., 1995. Decadal trends in the North Atlantic Oscillation: regional temperatures 1067 and precipitation. Science 269, 678-679.

1068 Inman, D.L., Frautschy, J.D., 1966. Littoral processes and the development of shorelines. 1069 Proceedings Coastal Engineering Conference, ASCE, pp. 511-536. 
1070 IPCC, 2007. Climate Change 2007: Impacts, Adaptation and Vulnerability. in: M.L. Parry, 1071 O.F. Canzioni, J.P. Palutikof, J.P. van der Linden, C.E. Hanson (eds) Contribution of 1072 Working Group II to the Fourth Assessment Report of the Intergovernmental Panel on 1073 Climate Change. Hanson, Cambridge University Press., pp. 7-22.

1074 Iskander, M.M., Frihy, O.E., EL Ansary, A.E., El Mooty, M.M.A., Nagy, H.M., 2007. Beach 1075 impacts of shore-parallel breakwaters backing offshore submerged ridges, Western 1076 Mediterranean Coast of Egypt. Journal of Environmental Management 85, 1109-1119. James, L.A., Hodgson, M.E., Ghoshal, S., Megison Latiolais, M., 2012. Geomorphic change 1078 1079

1080 Jenkinson, A.F., Collinson, B.P., 1977. An initial climatology of gales over the North Sea. 1081 Synoptic Climatology Branch Memorandum 62, Meteorological Office, Bracknell. Jones, P.D., Hulme, M., Briffa, K.R., 1993. A comparison of Lamb circulation types with an objective classification scheme. International Journal of Climatology 13, 655-663.

1084 Kaminsky, G. M., Ruggiero, P., Buijsman, M.C., McCandless, D., Gelfenbaum, G., 2010. 1085 Historical evolution of the Columbia River littoral cell. Marine Geology 273, 96-126.

King, C.A.M., 1964. The character of the offshore zone and its relationship to the foreshore 1087 near Gibraltar Point, Lincolnshire. East Midland Geographer 3, 230-243.

King, C.A.M., 1968. Beach measurements at Gibraltar Point, Lincolnshire. East Midland 1089 Geographer 4, 295-300.

1090 King, C.A.M., 1973. Dynamics of beach accretion in south Lincolnshire, England. In: D.R. 1091 Coates (ed) Coastal Geomorphology. Proceedings of the $3^{\text {rd }}$ Annual Geomorphology 1092 Symposium Series, Binghampton, New York. 73-98.

1093 King, C.A.M., Barnes, F.A., 1964. Changes in the configuration of the inter-tidal beach zone 1094 of part of the Lincolnshire coast since 1951. Zeitschrift für Geomorphologie 8, 105-126. Krueger, O., Von Storch, H., 2012. The informational value of pressure-based single-station 1096 proxies for storm activity. Journal of Atmospheric and Oceanic Technology 29, 569-580. Circulation Patterns, 1861-1971. Geophysical Memoir 116, HMSO, London, 85 pp. 
Lee, M., 2001. Coastal defence and the Habitats Directive: predictions of habitat change in England and Wales. Geographical Journal 167, 39-56.

Leggett, D.J., Lowe, J.P., Cooper, N.J., 1998. Beach evolution on the Southern Sea coast. Coastal Engineering 26, 2759-2772.

Lim, M., Rosser, N.J., Allison, R.J., Petley, D.N. 2010. Erosional processes in the hard rock coastal cliffs at Staithes, North Yorkshire. Geomorphology 114, 12-21.

Longley, P.A., Goodchild, M.F., Maquire, D.J., Rhind, D.W., 2005. Geographic Information Systems and Science $2^{\text {nd }}$ edition, Wiley, London.

Lorenzo, M.N., Taboada, J.J., Gimeno, L. 2008. Links between circulation weather types and teleconnection patterns and their influence on precipitation patterns in Galicia (NW Spain). International Journal of Climatology 28, 1493-1505.

McCave, I.N. 1987. Fine sediment sources and sinks around the East Anglian coast. Journal of the Geological Society of London 144, 149-152.

MAFF 1994. Shoreline Management Plans: a guide for operating authorities. Ministry of Agriculture, Fisheries and Food and the Welsh Office, London.

Mason, S.J., Hansom, J.D., 1988. Cliff erosion and its contribution to a sediment budget for part of the Holderness coast, England. Shore and Beach 56 (4), 30-38.

Masselink, G., Hughes, M.G., 2003. Introduction to Coastal Processes and Geomorphology, Hodder Arnold, Hodder Headline Group, London.

Maune, D.F. 2007. Digital Elevation Model Technologies and Applications: The DEM Users Manual $2^{\text {nd }}$ edition. American Society for Photogrammetry and Remote Sensing, Bethesda.

May, V., Hansom, J., 2003. Coastal Geomorphology of Great Britain. No. 28 in Geological Conservation Review Series. Joint Nature Conservation Committee, Peterborough

Moore, T., Morris, K., Blackwell, G., Gibson, S., Stebbing, A., 1998. An expert system for integrated coastal zone management: a geomorphological case study. Marine Pollution Bulletin 37, 361-370.

Morton, R.A., and Sallenger, A.H., Jr., 2003. Morphological impacts of extreme storms on sandy beaches and barriers. Journal of Coastal Research 19, 560-573.

Motyka, J.M., Brampton, A.H., 1993. Coastal mapping-mapping of Littoral cells, Technical report SR 328, HR Wallingford Ltd, 102 pp. 
1129 Neill, S.P., Elliott, A.J., Hashemi, M.R. 2008. A model of interannual variability in beach 1130 levels. Continental Shelf Research 28, 1769-1781.

1131 Newsham, R., Balson, P.S., Tragheim, D.G., Denniss, A.M., 2002. Determination and prediction of sediment yields from recession of the Holderness Coast, NE England. Journal of Coastal Conservation 8, 49-54.

O'Connor, M.C., Cooper, J.A.G., Jackson, D.W.T., 2011. Decadal behavior of tidal inletassociated beach systems, northwest Ireland in relation to climate forcing. Journal of Sedimentary Research 81, 38-51.

O'Connor, M.C., Lymberry, G., Cooper, J.A.G., Gault, J., McKenna, J. 2009. Practice versus policy-led coastal defence management. Marine Policy 33, 923-929.

1139 Orford, J.D., Carter R.W.G., Jennings S.C., Hinton A.C. 1995. Processes and timescales by 1140 which a coastal gravel-dominated barrier responds geomorphologically to sea-level rise: 1141 Story Head barrier, Nova Scotia. Earth Surface Processes and Landforms 20, 21-37.

1142 Orford, J.D., Cooper, A.G., McKenna, J., 1999. Mesoscale temporal changes to foredunes at 1143 Inch Spit, south-west Ireland. Zeitschrift für Geomorphologie 43 (4), 439-461.

1144 Orford, J.D., Pethick, J., 2006. Challenging assumption of future coastal habitat development 1145 around the UK. Earth Surface Processes and Landforms 31, 1625-1642.

1146 Pajak, M.J., Leatherman, S., 2002. The high water line as shoreline indicator. Journal of 1147 Coastal Research 18, 329-337.

1148 Parker, J.A., Foden, D., 2009. High-resolution measurement of a North Sea storm surge. 1149 Journal of Coastal Research SI 56, 1656-1660.

1150 Pethick, J., 2001. Coastal management and sea-level rise. Catena 42, 307-322.

1151 Pethick, J S., 1994. Humber estuary and coast - management issues. Report by: Institute of 1152 Estuarine and Coastal Studies, University of Hull, for Humberside County Council.

1153 Pethick, J.S. 1996. Coastal slope development: temporal and spatial periodicity in the 1154 Holderness cliff recession. In Anderson, M.G., Brooks, S.M. (eds). Advances in Hillslope 1155 Processes. Wiley, Chichester, vol. 2, 897-917.

1156 Posford Duvivier, 1992. Easington Coast Protection. Report to Holderness Borough Council. 1157 Posford Duvivier, Peterborough. 
Pringle, A.W., 1985. Holderness coast erosion and the significance of ords. Earth Surface Processes and Landforms 10, 107-124.

Pye, K., 1983. Coastal dunes. Progress in Physical Geography, 31, pp 249-266.

Pye, K., 1995. Controls on long-term saltmarsh accretion and erosion in the Wash, Eastern England. Journal of Coastal Research 11, 337-356.

Pye, K., Blott, S.J., 2008. Decadal-scale variation in dune erosion and accretion rates: an investigation of the significance of changing storm tide frequency and magnitude on the Sefton coast, UK. Geomorphology 102, 652-666.

Pye, K., Blott, S.J., 2010. Aldbrough gas storage project: geomorphological assessment of impact of proposed cliff protection works on adjoining areas, report no EX1214, 16 pp.

Pye, K., Saye, S.E., Blott, S.J., 2007. Sand Dune Processes and Management for Flood and Coastal Defence. Part 1: Project Overview and Recommendations. RandD Technical Report FD1302/TR/1, Department for Environment, Food and Rural Affairs, London, 35pp.

Quinn, J.D., Philip, L.K., Murphy, W., 2009. Understanding the recession of the Holderness Coast, east Yorkshire, UK: a new presentation of temporal and spatial patterns. Quarterly Journal of Engineering Geology and Hydrogeology 42, 165-178.

Reid, C. 1885. Memoirs of the Geological Survey of England and Wales. The Geology of Holderness, and the Adjoining Parts of Yorkshire and Lincolnshire. HMSO, London.

Robinson, A.H.W., 1964. The inshore waters, sediment supply and coastal changes of part of Lincolnshire. East Midland Geographer 3, 22,307-22,321.

Robinson, A.H.W., 1968. The use of sea bed drifter in coastal studies with particular reference to the Humber. Zeitschrift für Geomorphologie 7, 1-23.

Robinson, D.N., 1953. The storm surge $31^{\text {st }}$ January- $1^{\text {st }}$ February, 1953 and the associated meterological and tidal conditions. Geography 38, 134-141.

Robinson D.N., 1984. The Saltfleetby-Theddlethorpe coastline. Transactions of the Lincolnshire Naturalists' Union 21, 1-12.

Ruessink, B.G., Jeuken, M.C.J.L.L., 2002. Dunefoot dynamics along the Dutch coast. Earth Surface Processes and Landforms 2, 1043-1056. 
1186 Ruggiero, P., Kaminsky, G.M., Gelfenbaum, G., Voigt, B. 2005. Seasonal to interannual 1187 morphodynamics along a high-energy dissipative littoral cell. Journal of Coastal Research $118821,553-578$.

1189 Saye, S.E., van der Wal, D., Pye, K., Blott, S.J. 2005. Beach-dune morphological 1190 relationships and erosion/accretion: an investigation at five sites in England and Wales using 1191 LIDAR data. Geomorphology 72, 128-55.

Schans, H., Möller, I., Spencer, T., 2001. Large-scale classification of the East Anglian coastline, UK. Coastal Dynamics '01. Proceedings of the 4th International Conference on Coastal Dynamics, Lund, Sweden. ASCE, 683 - 692.

Scott Wilson, 2009. Flamborough Head to Gibraltar Point Shoreline Management Plan. Appendix C - Assessment of Coastal Behaviour and Baseline Scenarios. Scott Wilson, Basingstoke.

1198 Steers, J.A., 1946. The Coastline of England and Wales. Cambridge University Press, 1199 Cambridge. 644 pp.

1200 Steers, J.A., 1966. Holderness, Lincolnshire and the Fenland, in: Steers, J.A. (Eds) The 1201 coastline of England and Wales. Cambridge University Press, Cambridge, pp. 406-440.

1202 Steers, J.A., Stoddart, D.R., Bayliss-Smith, T.P., Spencer, T., Durbridge, P.M. 1979. The 1203 1204

1205

Stockdon, H.F., Sallenger Jr., A.H., Holman, R.A., Howd, P.A., 2007. A simple model for the 1206 spatially-variable coastal response to hurricanes. Marine Geology 238, 1-20.

1207 Swinnerton, H.H., Kent, P.E. 1949. The Geology of Lincolnshire. Lincolnshire Naturalists 1208 Union, Lincoln.

1209 Thieler, E. R., Danforth, W.W., 1994. Historical shoreline mapping (I): Improving technique and reducing position errors. Journal of Coastal Research 19 (3), 549-563.

1211 Thieler, E.R., Himmelstoss, E.A., Zichichi, J.L., Ergul, A., 2009, Digital Shoreline Analysis 1212 System (DSAS) version 4.0-An ArcGIS extension for calculating shoreline change: U.S. 1213 Geological Survey Open-File Report 2008-1278. Available online at 1214 http://pubs.usgs.gov/of/2008/1278/. 
1215 Thomas, T., Phillips, M.R., Williams, A.T., Jenkins, R.E., 2011. A multi-century record of 1216 linked nearshore and coastal change. Earth Surface Processes and Landforms 36, 99512171006.

1218 Tonk, A.M., 2000. Monitoring changes in coastal morphology. North Lincolnshire, report to 1219 Environmnent Agency, 44 pp.

1220 Townend, I., Whitehead, P. 2003. A preliminary net sediment budget for the Humber 1221 Estuary. The Science of the Total Environment 314-316, 755-767.

1222 Townend, I., Wang, Z.B., Rees, J.G. 2007. Millenial to annual volume changes in the 1223 Humber Estuary. Proceedings: Mathematical, Physical and Engineering Sciences 463, 8371224854.

1225 Trigo, R.M., Dacamara, C.C. 2000. Circulation weather types and their influence on the 1226 precipitation regime in Portugal. International Journal of Climatology 20, 1559-1581.

1227 Tsimplis, M.N., Woolf, D.K., Osborn, T.J., Wakelin, S., Wolf, J., Flather, R., Shaw, A.G.P., 1228 Woodworth, P., Challenor, P., Blackman, D., Pert, F., Yan, Z., Jevrejeva, S., 2005. Towards 1229 a vulnerability assessment of the UK and northern European coasts: the role of regional 1230 climate variability. Philosophical Transactions of the Royal Society 363, 1329-1358. Valentin, H., 1971. Land loss at Holderness, in Steers, J.A. (Eds.), Applied Coastal Geomorphology, Macmillan, London, pp. 116-137. Valentin, H., 1954. Der landverlust in Holderness, Ostengland, von 1852-1952. Die Erde 6, 296-315.

1235 van Houwelingen, S.T., Masselink, G., Bullard, J. 2006. Characteristics and dynamics of 1236 multiple intertidal bars, north Lincolnshire, England. Earth Surface Processes and 1237 Landforms, 31, 428-443.

1238 van Houwelingen, S.T., Masselink, G., Bullard, J. 2008. Dynamics of multiple intertidal bars 1239 over semi-diurnal and lunar tidal cycles, North Lincolnshire, England. Earth Surface 1240 Processes and Landforms, 33, 1473-1490.

1241 Vasseur, B., Héquette, A., 2000. Storm surges and erosion of coastal dunes between 1957 1242 and 1988 near Dunkerque (France), southwestern North Sea. Coastal and Estuary 1243 Environments. Geological Society. Sp. Publ., 175, 99-107. 
1244 Vespremeanu-Stroe, A., Constantinescu, S., Tătui,F., Giosan, L., 2007. Multi-decadal 1245 evolution and North Atlantic Oscillation influences on the dynamics of the Danube delta 1246 shoreline. Journal of Coastal Research SI 50, 157-162.

1247 Wang, X.L., Zwiers, F.W., Swail, V.R., Feng, Y. 2009. Trends and variability of storminess in 1248 the Northeast Atlantic region, 1874-2007. Climate Dynamics 33, 1179-1195.

1249 Wang, X.L., Wan, H., Zwiers, F.W., Swail, V.R., Compo, G.P., Allan, R.J., Vose, R.S., 1250 Jourdain, S., Yin, X. 2011. Trends and low-frequency variability of storminess over western 1251 Europe, 1878-2007. Climate Dynamics 37, 2355-2371.

1252 Webster, P. J., Holland, G. J., Curry, J. A., Chang, H-R., 2005. Changes in tropical cyclone 1253 number, duration and intensity in a warming environment. Science 309, 1844-1846.

1254 Wilby, R.L., Dalgleish, H. Y., Foster, I.D.L., 1997. The impact of weather patterns on historic 1255 and contemporary catchment sediment yields. Earth Surface processes and landforms 22, 1256 353-363.

1257 Woodworth, P.L., Teferle, F.N., Bingley, R.M., Shennan, I., Williams, S.D.P., 2009. Trends in 1258 UK mean sea level revisited, Geophysical Journal International 176, 19-30.

1259 Woolf, D.K., Cotton, P.D., Challenor, P.G., 2003. Measurements of the offshore wave 1260 climate around the British Isles by satellite altimeter, Philosophical Transactions of the Royal 1261 Society $361,27-31$.

1262 Woolf, D.K., Challenor, P.G., Cotton,P.D., 2002. The variability and predictability of the North 1263 Atlantic wave climate. Journal of Geophysical Research 107 (C10), 3145-3159.

1264 Zhang, K., Douglas, B. C. and Leatherman, S. P., 2001. Beach Erosion Potential for Severe 1265 Nor'easters. Journal of Coastal Research 17, 309-321. 


\section{Table Captions}

Table 1 Tidal levels and tidal ranges, expressed in metres above Ordnance Datum Newlyn (ODN). Tide level for East Riding coast derived from Spurn Head data taken from Admiralty Tide Tables (Admiralty, 2009) and from tidal statistics at Skegness derived from POLTIPS 3 software developed by the National Oceanography Centre Liverpool (NOC, 2009). Abbreviations: HAT - Highest Astronomical Tide; MHWS - Mean High Water Spring; MHWN - Mean High Water Neap; MLWN - Mean Low Water Neap; MLWS - Mean Low Water Spring; LAT - Lowest Astronomical Tide.

Table 2 Summary characteristics of the six areas of interest (AOIs) examined in detail. Profile labels correspond to original data sources (East Riding Yorkshire Council or UK Environmental Agency).

Table $3 \quad$ Summary of map and aerial photograph source documents and characteristics for each AOI. Abbreviations: B\&W - black and white, EA - UK Environment Agency. For AOI information, see Table 2.

Table 4. Correlation table between morphology parameters and forcing factors at the sandy beaches between surveys (AOIs 2, 3, 5): $\mathrm{Cl}$ - Relative coastline position, $\mathrm{C}_{\mathrm{HAT}}$ - HAT level position, $\mathrm{V}_{\mathrm{B}}$ - sand volume in backshore, $\mathrm{V}_{\mathrm{F}}$ - sand volume in foreshore, SS - storm surge. Correlation values above \pm 0.5 are in bold.

Table 5 Estimated inter-survey and cumulative sediment volume changes for the periods 1994/97-1999, 1999-2005, 2005-2008, 2008-2010, by shore units (see Fig. 2). Positive values indicate accretion, and negative values erosion.

Estimated inter-survey and cumulative volumetric changes for the periods 1994/97-1999, 1999-2005, 2005-2008, 2008-2010, by nearshore sub-unit (see Fig. 2). Positive values indicate accretion, and negative values erosion. 


\section{Figure Captions}

Figure 1 Inset: Distribution of coastal cells around the coast of England and Wales, Main figure: Boundaries and major features of sediment cell 2, east coast of England.

Figure 2 Schematic diagram defining the limits of the backshore, foreshore and nearshore zones used to calculate sediment budget.

Figure 3 Changes in coastline position within sediment cell 2 from Flamborough Head (P1) to Gibraltar Point (L2A7) over the period from mid-1990 to 2010 (longshore spacing not to scale). Coastline represented by the cliff base (East Riding; P1-121) or HAT (Spurn Head; P122-P134 and Lincolnshire coast; L1A1-L2A7). Zero line represents the initial survey in 1994/96/97 along East Riding coast and 1997 along Lincolnshire coast. Profile labels correspond to original data sources (East Riding Yorkshire Council or UK Environmental Agency). Notation of AOls is indicated - see Table 2. Profiles perpendicular to coastal defences and lagoons are excluded (P3-P7, P42-P44, P90-P93, P115-P118, P133, L2A4).

Figure 5 Position of coastlines from 1891 to date for: A) Donna Nook, B) Saltfeetby, C) Theddlethorpe superimposed on ortho-photographs in 2010. Evolution of the coastline position (line curve) relative to OS maps in 1891 at D) Donna Nook, F) Theddlethorpe and in 1994 at E) Saltfeetby. Dashed line corresponds to mean long-term rate of shoreline evolution over the timeframe.

Figure 6 Position of coastline from 1891 to date for Skegness: A) North, B) South.

Figure $7 \quad$ Annual frequency of storm surge and coastline evolution between 1994/972010 at: A) Easington, B) North Spurn Head, C) Donna Nook, D) Saltfleetby, E) Theddlethorpe, and F) Skegness.

Figure 8 Time series of JWT annual strong wind events and storm surge measured at tide gauges between 1994 and 2010 
1333

1334

1335

1336

1337

1338

1339

1340

1341

1342

1343
Figure 9 Time series of JWT annual storm wind events between 1871-2010 for A) onshore winds, B) alongshore winds and C) offshore winds. In each case daily frequency and 5-year running mean are shown. Note: vertical scales differ.

Figure 10 Time series of: A) JWT annual strong onshore wind events between 18712010, B) winter NAO values (Dec-March) between 1850-2010 and coastline evolution at C) Easington, D) North Spurn Head, E) Donna Nook, and F) Theddlethorpe from 1854/91 to 2010.

Figure 11 Long-term morphodynamic trends in the coastal cell along East Riding and Lincolnshire coasts at the studied AOIs since 1850/81. 
1 Table 1 Tidal levels and tidal ranges, expressed in metres above Ordnance Datum

2 Newlyn (ODN). Tide level for East Riding coast derived from Spurn Head data taken from

3 Admiralty Tide Tables (Admiralty, 2009) and from tidal statistics at Skegness derived from

4 POLTIPS 3 software developed by the National Oceanography Centre Liverpool (NOC,

5 2009). Abbreviations: HAT - Highest Astronomical Tide; MHWS - Mean High Water Spring;

6 MHWN - Mean High Water Neap; MLWN - Mean Low Water Neap; MLWS - Mean Low

7 Water Spring; LAT - Lowest Astronomical Tide.

8

\begin{tabular}{lllllll}
\hline Coastal region & HAT & MHWS & MHWN & MLWN & MLWS & LAT \\
\hline East Riding & 3.80 & 3.00 & 1.60 & -1.20 & -2.70 & -3.70 \\
Lincolnshire & 4.09 & 3.20 & 1.70 & -1.09 & -2.59 & -3.57 \\
\hline
\end{tabular}

9

10

11 
1 Table 2 Summary characteristics of the six areas of interest (AOIs) examined in detail. Profile labels correspond to original data sources (East Riding Yorkshire Council or UK Environmental Agency).

\begin{tabular}{|c|c|c|c|c|c|c|c|}
\hline \multirow[t]{2}{*}{$\mathrm{AOI}$} & \multirow{2}{*}{$\begin{array}{l}\text { Sediment } \\
\text { cell }\end{array}$} & \multirow[t]{2}{*}{ Location } & \multicolumn{2}{|c|}{ Geomorphology } & \multirow{2}{*}{$\begin{array}{l}\text { Alongshore } \\
\text { length }(\mathrm{km})\end{array}$} & \multirow[t]{2}{*}{ Profiles } & \multirow{2}{*}{$\begin{array}{c}\text { No. } \\
\text { Transects } \\
\text { used in } \\
\text { DSAS }\end{array}$} \\
\hline & & & $\begin{array}{l}\text { Landward } \\
\text { features }\end{array}$ & $\begin{array}{c}\text { Near/ } \\
\text { Offshore } \\
\text { features }\end{array}$ & & & \\
\hline 1 & $2 a$ & $\begin{array}{l}\text { Easington } \\
\text { (E) }\end{array}$ & $\begin{array}{c}\text { Clay strata } \\
\text { and cliff from } \\
9 \mathrm{~m} \text { to } 5.3 \mathrm{~m} \\
\text { high }\end{array}$ & & 5.2 & $\mathrm{P} 113-\mathrm{P} 121$ & 43 \\
\hline 2 & $2 a$ & $\begin{array}{l}\text { North } \\
\text { Spurn } \\
\text { Head } \\
\text { (NSP) }\end{array}$ & $\begin{array}{l}\text { Sand spit of } \\
\text { c. } 5 \mathrm{~km} \text { length }\end{array}$ & $\begin{array}{c}\text { Glacial } \\
\text { ridge of } \\
\text { clay banks }\end{array}$ & 1.4 & P122-P124 & 17 \\
\hline 3 & $2 b$ & $\begin{array}{l}\text { Donna } \\
\text { Nook } \\
(\mathrm{DN})\end{array}$ & $\begin{array}{c}\text { Coastal } \\
\text { dunes and } \\
\text { clay } \\
\text { embankment }\end{array}$ & $\begin{array}{c}\text { Sand banks } \\
\text { of morainic } \\
\text { material }\end{array}$ & 5.1 & L1A1-L1A6 & 34 \\
\hline 4 & $2 c$ & $\begin{array}{l}\text { Saltfleet- } \\
\text { by (SA) }\end{array}$ & Saltmarsh & $\begin{array}{c}\text { Sand banks } \\
\text { of morainic } \\
\text { material }\end{array}$ & 4.1 & L2E1-L2E4 & 30 \\
\hline 5 & $2 c$ & $\begin{array}{l}\text { Theddle- } \\
\text { thorpe } \\
(\mathrm{TH})\end{array}$ & $\begin{array}{l}\text { Coastal } \\
\text { dunes }\end{array}$ & $\begin{array}{c}\text { Sand banks } \\
\text { of morainic } \\
\text { material }\end{array}$ & 4.9 & L2E5-L2D1 & 44 \\
\hline 6 & $2 c$ & $\begin{array}{l}\text { Skegness } \\
\text { (SK) }\end{array}$ & $\begin{array}{l}\text { Engineering } \\
\text { defences } \\
\text { Erosive clay } \\
\text { strata }\end{array}$ & & 5 & L2B6-L2A3 & 57 \\
\hline
\end{tabular}


1 Table 3 Summary of map and aerial photograph source documents and

2

3

4

\begin{tabular}{|c|c|c|c|c|c|}
\hline $\mathrm{AOI}$ & Year & Type & Source & Document type & Scale \\
\hline $\mathrm{EA}, \mathrm{NSH}$ & $\begin{array}{l}1854,1890, \\
1951\end{array}$ & OS map & Edina & Geo-referenced & $1: 10560$ \\
\hline $\begin{array}{l}\text { DN, SA, } \\
\text { TH, SK }\end{array}$ & $\begin{array}{l}1891,1910, \\
1951\end{array}$ & OS map & Edina & Geo-referenced & $1: 10560$ \\
\hline $\mathrm{EA}, \mathrm{NSH}$ & 1966 & $\begin{array}{l}\text { B\&W } \\
\text { Aerial photo }\end{array}$ & $\begin{array}{l}\text { English Heritage } \\
\text { and EA }\end{array}$ & $\begin{array}{l}\text { Scan from print } \\
\text { photograph (600dpi) }\end{array}$ & $1: 7500$ \\
\hline $\mathrm{EA}, \mathrm{NSH}$ & $\begin{array}{l}2005,2008, \\
2010\end{array}$ & $\begin{array}{l}\text { Colour } \\
\text { Aerial photo }\end{array}$ & $\begin{array}{l}\text { East Riding } \\
\text { Yorkshire Council }\end{array}$ & $\begin{array}{l}\text { Digital ortho- } \\
\text { georeferenced }\end{array}$ & $1: 5000$ \\
\hline DN & 1970 & $\begin{array}{l}\text { B\&W } \\
\text { Aerial photo }\end{array}$ & English Heritage & $\begin{array}{l}\text { Scan from print } \\
\text { photograph (600dpi) }\end{array}$ & $1: 7500$ \\
\hline $\mathrm{TH}$ & $\begin{array}{l}1953,1966, \\
1976,1983\end{array}$ & $\begin{array}{l}\text { B\&W } \\
\text { Aerial photo }\end{array}$ & Natural England & $\begin{array}{l}\text { Scan from print } \\
\text { photograph (600dpi) }\end{array}$ & $1: 7500$ \\
\hline $\begin{array}{l}\text { DN, SF, } \\
\text { TH, SK }\end{array}$ & 1994, 1999 & $\begin{array}{l}\text { B\&W } \\
\text { Aerial photo }\end{array}$ & $\begin{array}{l}\text { Environment } \\
\text { Agency }\end{array}$ & $\begin{array}{l}\text { Scan from print } \\
\text { photograph (600dpi) }\end{array}$ & $1: 5000$ \\
\hline $\begin{array}{l}\text { DN, SF, } \\
\text { TH, SK }\end{array}$ & $\begin{array}{l}2005,2008, \\
2010\end{array}$ & $\begin{array}{l}\text { Colour } \\
\text { Aerial photo }\end{array}$ & $\begin{array}{l}\text { Environment } \\
\text { Agency }\end{array}$ & $\begin{array}{l}\text { Digital ortho- } \\
\text { georeferenced }\end{array}$ & $1: 5000$ \\
\hline
\end{tabular}
characteristics for each AOI. Abbreviations: B\&W - black and white. For AOI information, see Table 2. 
1 Table 4. Correlation table between morphology parameters and forcing factors at the 2 sandy beaches between surveys (AOIs 2, 3, 5): Cl - Relative coastline position, $\mathrm{C}_{\text {HAT }}$ - HAT 3 level position, $V_{B}$ - sand volume in backshore, $V_{F}$ - sand volume in foreshore, $S S$ - storm 4 surge. Correlation values above \pm 0.5 are in bold.

5

\begin{tabular}{|c|c|c|c|c|c|}
\hline & $\mathrm{Cl}$ & $\mathrm{C}_{\text {HAT }}$ & $V_{B}$ & $V_{F}$ & SS \\
\hline $\mathbf{C l}$ & & -0.112 & 0.538 & -0.011 & 0.733 \\
\hline $\mathrm{C}_{\text {HAT }}$ & & & 0.073 & 0.072 & -0.019 \\
\hline $\mathrm{V}_{\mathrm{B}}$ & & & & -0.528 & 0.656 \\
\hline$V_{F}$ & & & & & -0.508 \\
\hline
\end{tabular}

6

7

8 
1 Table 5 Estimated inter-survey and cumulative sediment volume changes in backshore and foreshore units (see Figure 2). Positive values indicate accretion, and negative values erosion.

\begin{tabular}{|c|c|c|c|c|c|c|c|}
\hline \multirow[b]{2}{*}{$\mathrm{AOI}$} & \multirow[b]{2}{*}{ Period } & \multicolumn{3}{|c|}{ Inter-survey change $\left(\mathrm{m}^{3} \times 10^{3}\right)$} & \multicolumn{3}{|c|}{ Cumulative change $\left(\mathrm{m}^{3} \times 10^{3}\right)$} \\
\hline & & Backshore & Foreshore & Total & Backshore & Foreshore & Total \\
\hline \multirow[t]{5}{*}{ Easington } & $1997 / 1999$ & -161.3 & -20.8 & -182.1 & -161.3 & -20.8 & -182.1 \\
\hline & $1999 / 2005$ & -175.9 & -60.0 & -235.9 & -337.2 & -60.0 & -397.2 \\
\hline & $2005 / 2008$ & -367.8 & -59.3 & -427.1 & -705.0 & -59.3 & -764.3 \\
\hline & $2008 / 2010$ & -127.2 & -37.8 & -165.0 & -832.3 & -37.8 & -870.0 \\
\hline & \multicolumn{4}{|c|}{ Rates of change $\left(\mathrm{m}^{3}\right.$ year $\left.^{-1}\right)$} & -64.0 & -2.9 & -66.9 \\
\hline North Spurn & $1997 / 1999$ & 8.4 & -1.9 & 6.5 & 8.4 & -1.9 & 6.5 \\
\hline \multirow[t]{4}{*}{ Head } & $1999 / 2005$ & -11.0 & 0.8 & -10.2 & -2.7 & -1.9 & -4.5 \\
\hline & $2005 / 2008$ & -13.0 & -22.8 & -35.9 & -15.7 & -1.9 & -17.6 \\
\hline & $2008 / 2010$ & -1.4 & -0.3 & -1.7 & -17.1 & -1.9 & -19.0 \\
\hline & & \multicolumn{3}{|c|}{ Rates of change $\left(\mathrm{m}^{3}\right.$ year $\left.^{-1}\right)$} & -1.3 & -0.1 & -1.5 \\
\hline \multirow[t]{5}{*}{ Donna Nook } & $1994 / 1999$ & 96.3 & 91.2 & 187.5 & 96.3 & 91.2 & 187.5 \\
\hline & $1999 / 2005$ & 497.5 & -109.0 & 388.6 & 593.8 & -17.7 & 576.1 \\
\hline & $2005 / 2008$ & -132.1 & -105.3 & -237.4 & 461.7 & -123.0 & 338.6 \\
\hline & $2008 / 2010$ & 26.5 & 432.7 & 459.2 & 488.1 & 309.7 & 797.8 \\
\hline & & \multicolumn{3}{|c|}{ Rates of change $\left(\mathrm{m}^{3}\right.$ year $\left.^{-1}\right)$} & 30.5 & 19.4 & 49.9 \\
\hline \multirow[t]{5}{*}{ Saltfleetby } & $1994 / 1999$ & 349.5 & 129.6 & 479.1 & 349.5 & 129.6 & 479.1 \\
\hline & $1999 / 2005$ & 66.4 & 173.7 & 240.1 & 415.9 & 303.3 & 719.2 \\
\hline & $2005 / 2008$ & -21.2 & -26.6 & -47.8 & 394.7 & 276.7 & 671.4 \\
\hline & $2008 / 2010$ & -24.2 & 12.7 & -11.5 & 370.6 & 289.4 & 659.9 \\
\hline & & \multicolumn{3}{|c|}{ Rates of change $\left(\mathrm{m}^{3}\right.$ year $\left.^{-1}\right)$} & 23.2 & 18.1 & 41.2 \\
\hline \multirow[t]{5}{*}{ Theddlethorpe } & $1994 / 1999$ & 681.8 & -435.4 & 246.4 & 681.8 & -435.4 & 246.4 \\
\hline & $1999 / 2005$ & 276.0 & 358.2 & 634.1 & 957.8 & -77.3 & 880.5 \\
\hline & $2005 / 2008$ & 423.0 & -330.3 & 92.7 & 1380.8 & -407.6 & 973.3 \\
\hline & $2008 / 2010$ & -372.1 & 160.6 & -211.5 & 1008.8 & -247.0 & 761.8 \\
\hline & & \multicolumn{3}{|c|}{ Rates of change $\left(\mathrm{m}^{3}\right.$ year $\left.^{-1}\right)$} & 63.0 & -15.4 & 47.6 \\
\hline \multirow[t]{5}{*}{ Skegness } & $1994 / 1999$ & 153.1 & -51.6 & 101.5 & 153.1 & -51.6 & 101.5 \\
\hline & $1999 / 2005$ & 48.6 & 107.6 & 156.2 & 201.7 & 56.0 & 257.7 \\
\hline & $2005 / 2008$ & -7.8 & 65.1 & 57.3 & 193.8 & 121.2 & 315.0 \\
\hline & $2008 / 2010$ & 67.9 & -38.3 & 29.6 & 261.7 & 82.9 & 344.6 \\
\hline & \multicolumn{4}{|c|}{ Rates of change $\left(\mathrm{m}^{3}\right.$ year $\left.^{-1}\right)$} & 16.4 & 5.2 & 21.5 \\
\hline
\end{tabular}


1 Table $6 \quad$ Estimated inter-survey and cumulative volumetric changes by nearshore sub2 unit (see Figure 2). Positive values indicate accretion, and negative values erosion.

\begin{tabular}{|c|c|c|c|c|c|c|c|}
\hline & \multirow[b]{2}{*}{ Period } & \multicolumn{3}{|c|}{$\begin{array}{l}\text { Nearshore inter-survey change } \\
\qquad\left(\mathrm{m}^{3} \times 10^{3}\right)\end{array}$} & \multicolumn{3}{|c|}{$\begin{array}{l}\text { Nearshore cumulative change } \\
\qquad\left(\mathrm{m}^{3} 10^{3}\right)\end{array}$} \\
\hline & & Sub-unit1 & Sub-unit2 & Total & Sub-unit1 & Sub-unit2 & Total \\
\hline \multirow[t]{3}{*}{ Donna Nook } & $1999 / 2005$ & 219.5 & 112.8 & 332.3 & 219.5 & 112.8 & 332.3 \\
\hline & $2005 / 2008$ & -187.6 & -73.0 & -260.6 & 31.9 & 39.8 & 71.8 \\
\hline & & \multicolumn{3}{|c|}{ Rates of change $\left(\mathrm{m}^{3}\right.$ year- $\left.{ }^{1}\right)$} & 3.5 & 4.4 & 8.0 \\
\hline \multirow[t]{3}{*}{ Saltfleetby } & $1999 / 2005$ & 140.3 & -223.4 & -83.1 & 140.3 & -223.4 & -83.1 \\
\hline & $2005 / 2008$ & -3.9 & 30.2 & 26.3 & 136.3 & -193.1 & -56.8 \\
\hline & & \multicolumn{3}{|c|}{ Rates of change $\left(\mathrm{m}^{3}\right.$ year $\left.^{-1}\right)$} & 15.1 & -21.5 & -6.3 \\
\hline \multirow[t]{3}{*}{ Theddlethorpe } & $1999 / 2005$ & -286.3 & 128.2 & -158.1 & -286.3 & 128.2 & -158.1 \\
\hline & $2005 / 2008$ & -14.3 & 70.8 & 56.4 & -572.7 & 256.5 & -316.2 \\
\hline & & \multicolumn{3}{|c|}{ Rates of change $\left(\mathrm{m}^{3}\right.$ year $\left.{ }^{-1}\right)$} & -63.6 & 28.5 & -35.1 \\
\hline \multirow[t]{3}{*}{ Skegness } & $1999 / 2005$ & 116.7 & 12.9 & 129.6 & 116.7 & 12.9 & 129.6 \\
\hline & $2005 / 2008$ & 25.3 & -34.2 & -8.9 & 142.0 & -21.3 & 120.7 \\
\hline & & \multicolumn{3}{|c|}{ Rates of change $\left(\mathrm{m}^{3}\right.$ year $\left.^{-1}\right)$} & 15.8 & -2.4 & 13.4 \\
\hline
\end{tabular}

4

5 


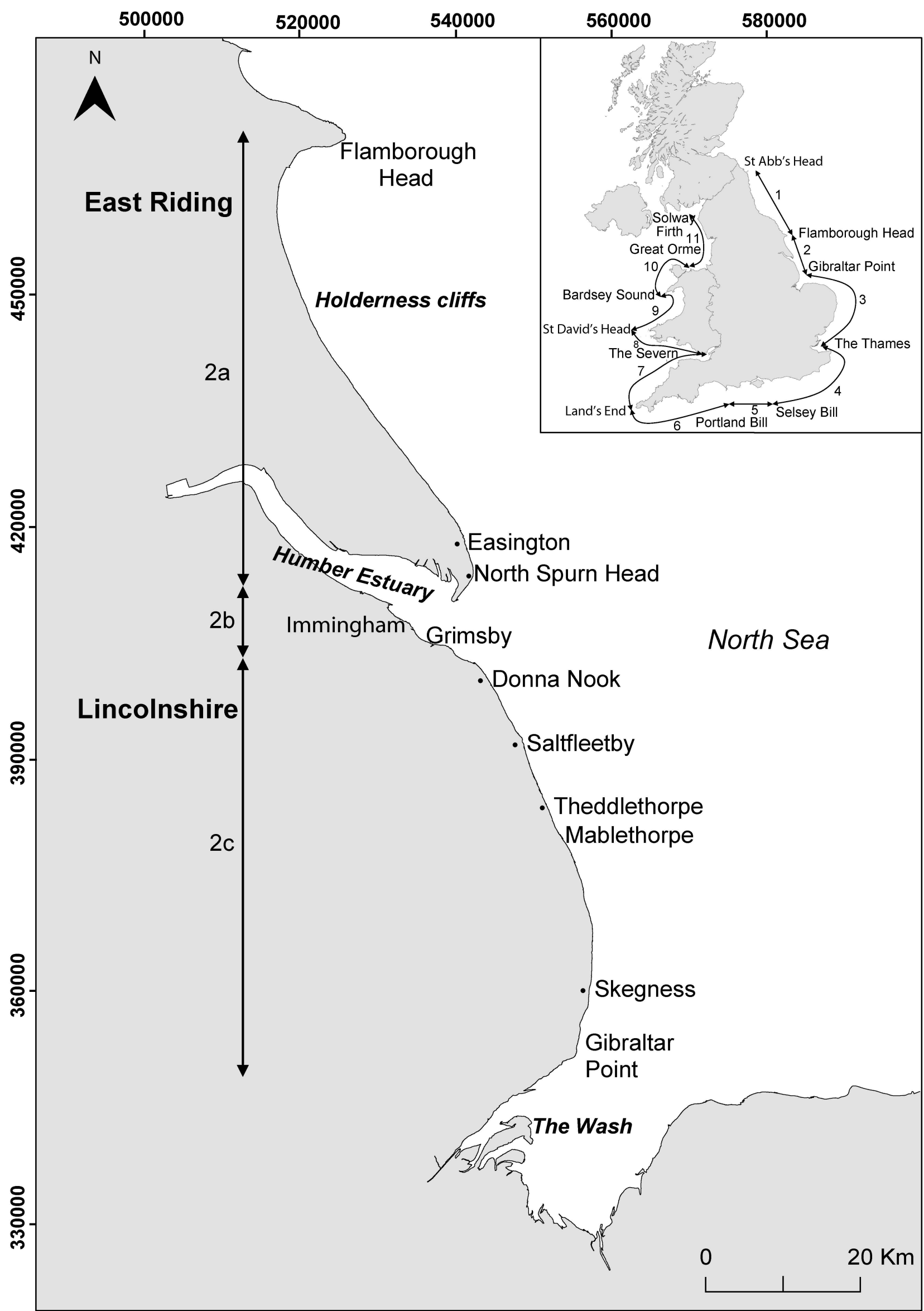




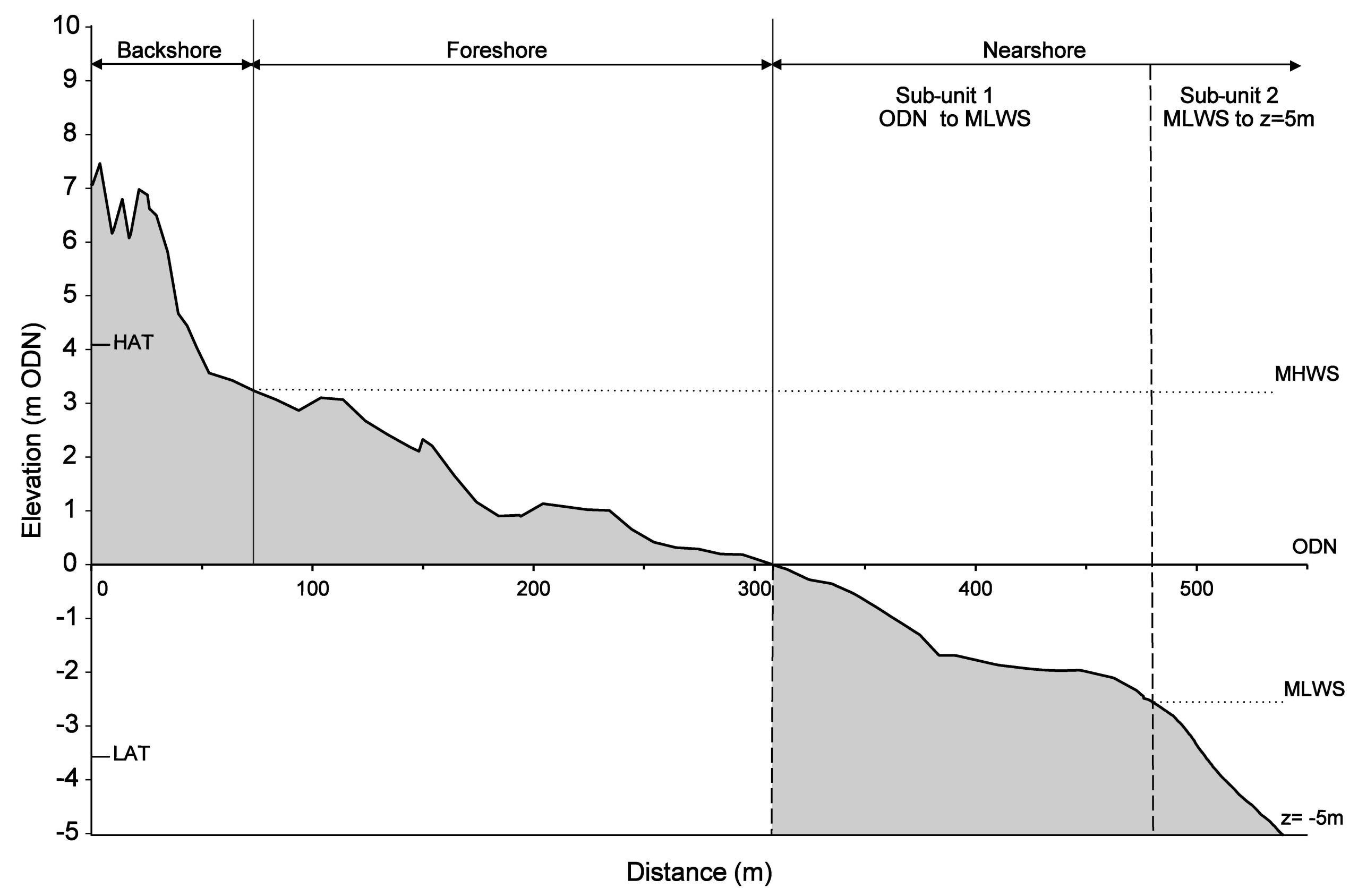




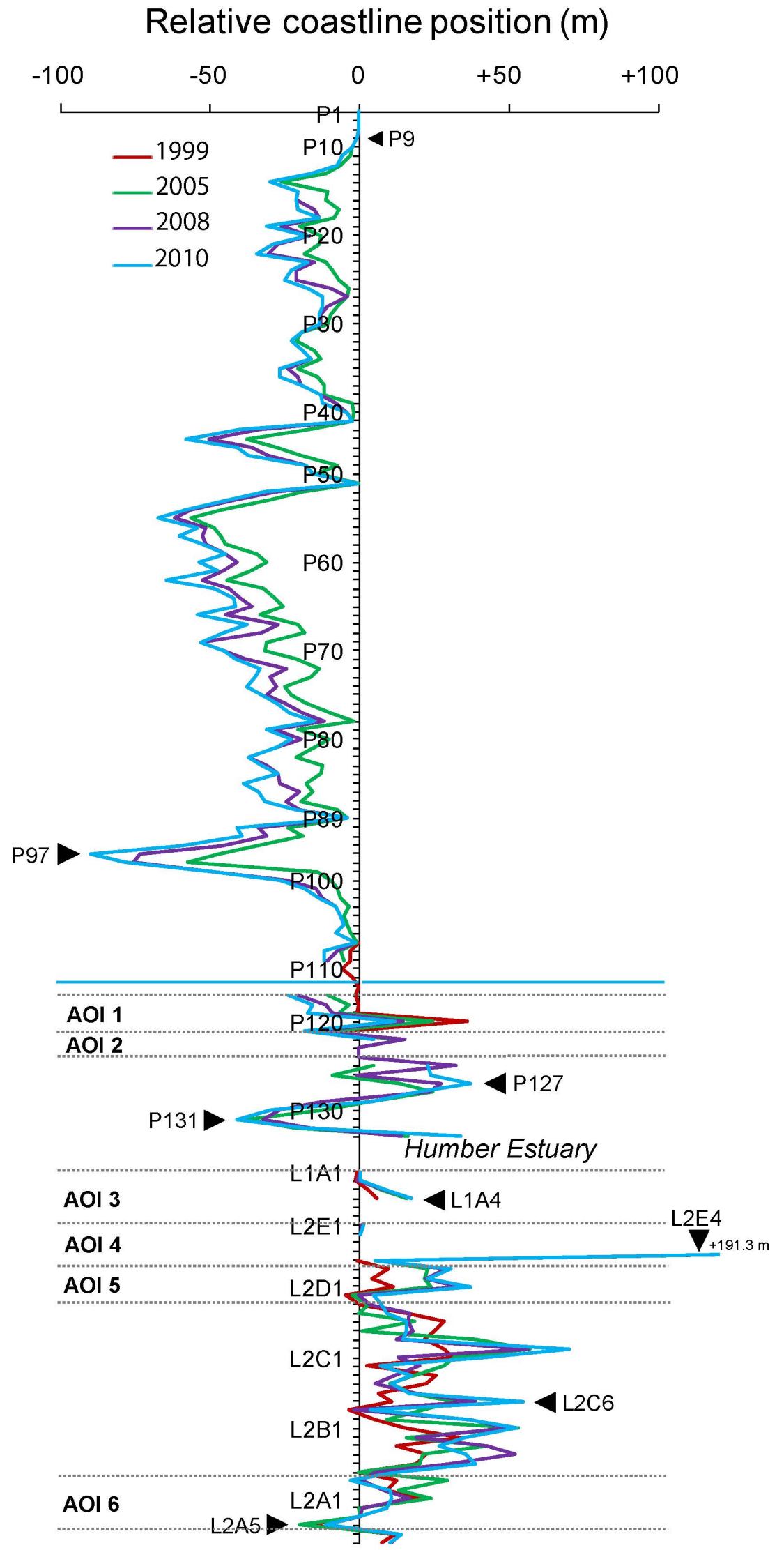

Erosion

Accretion 
A)

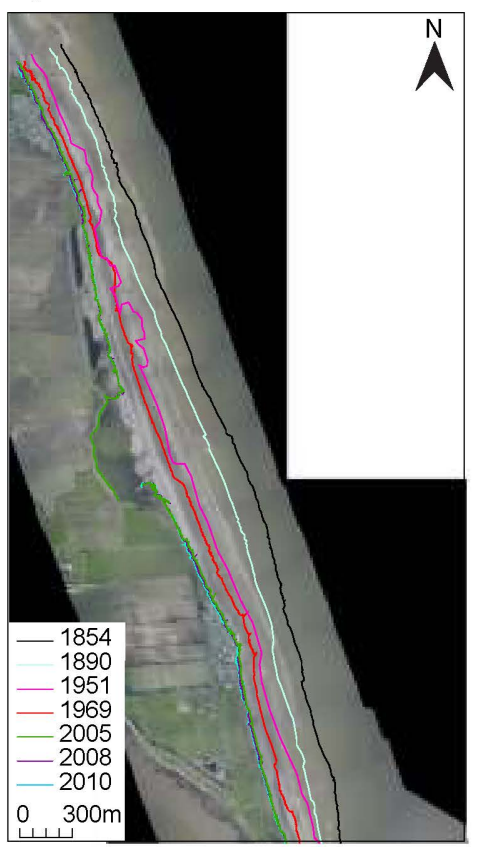

B)

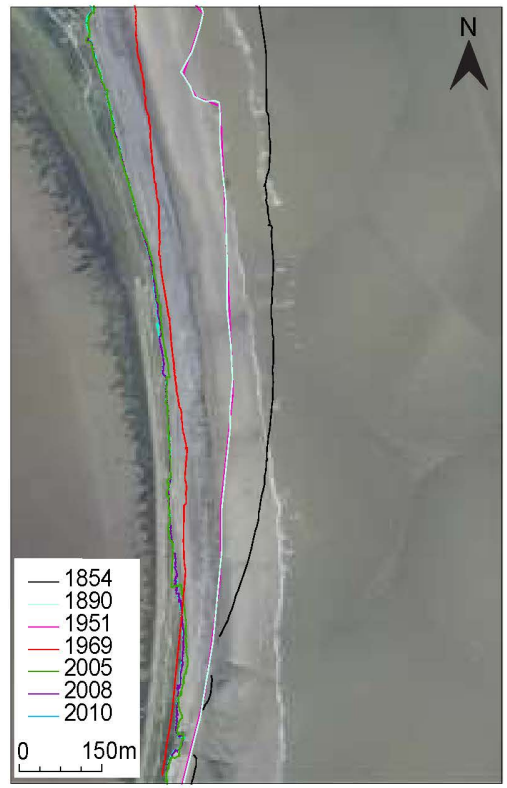

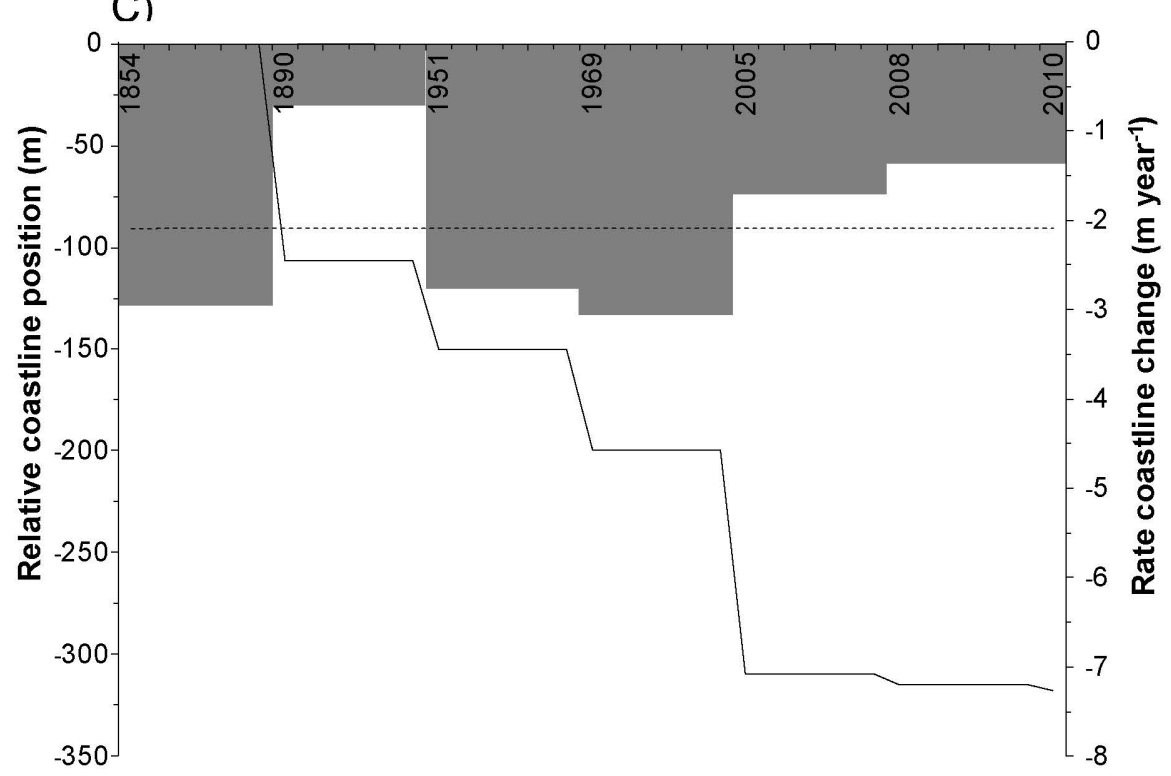

D)

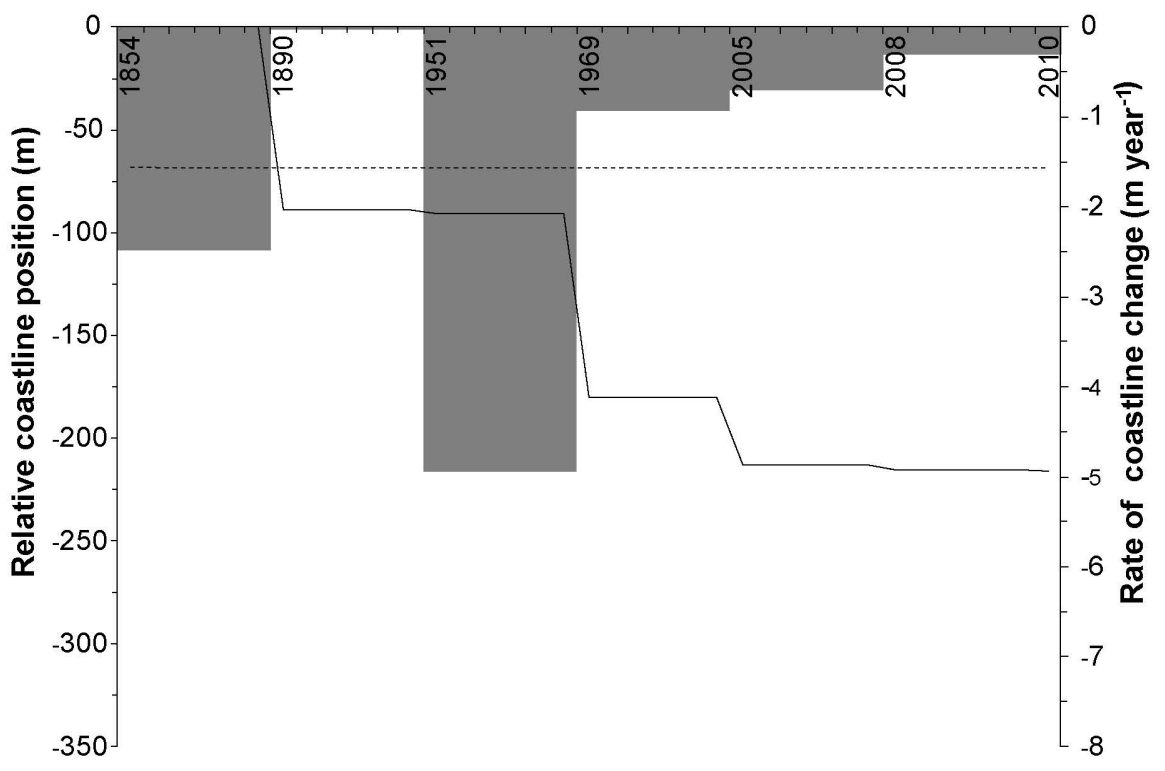



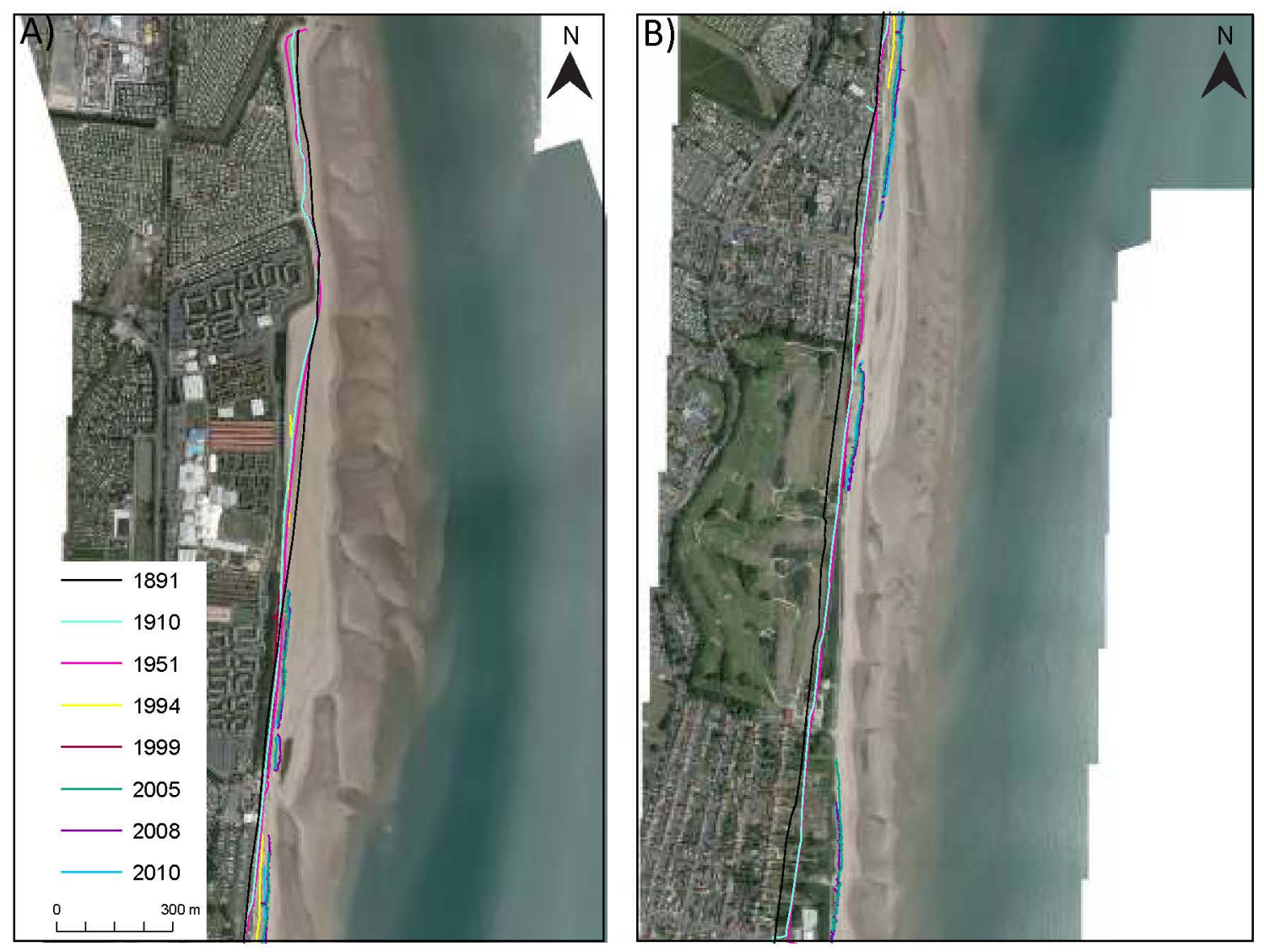

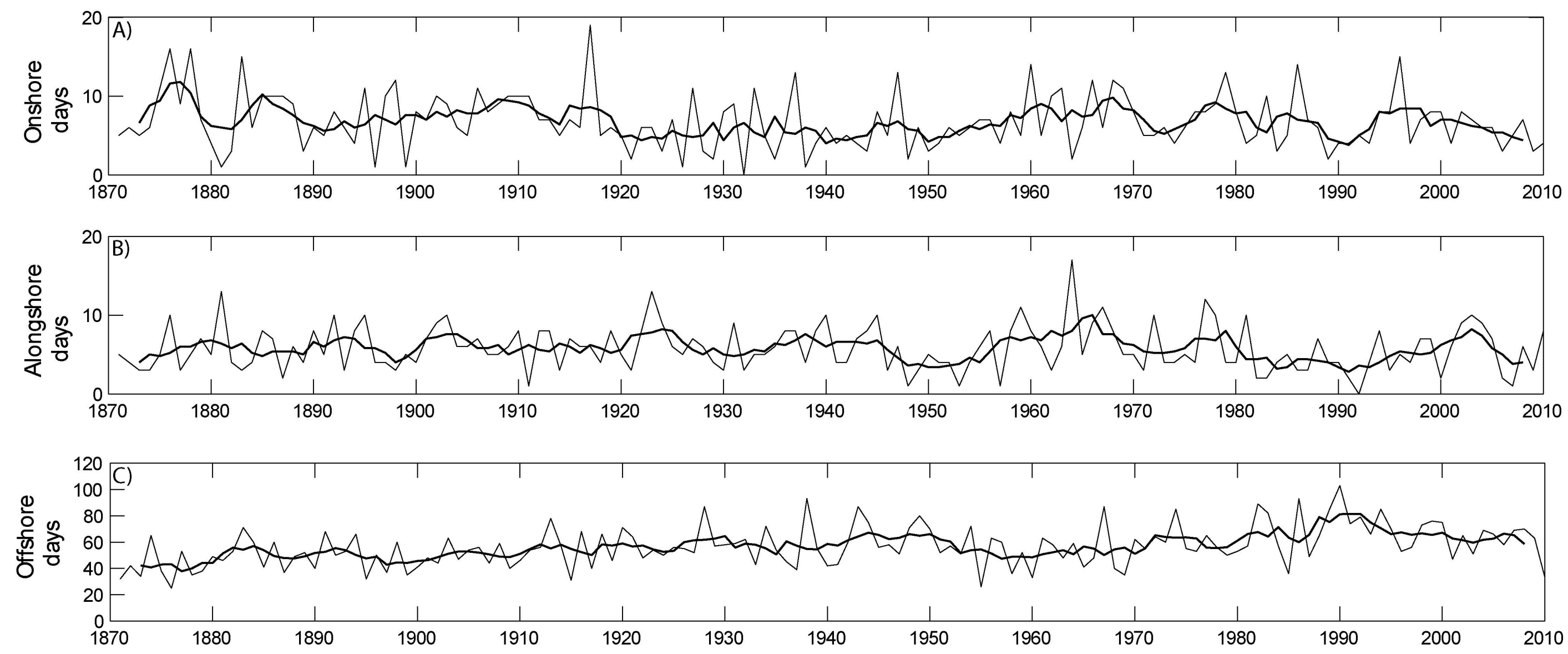


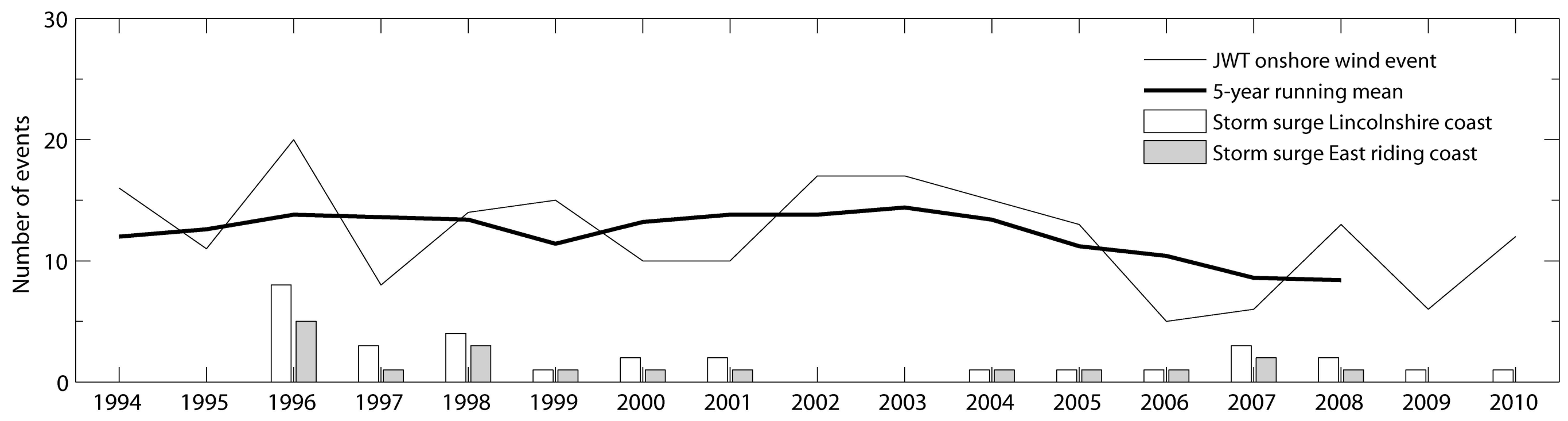



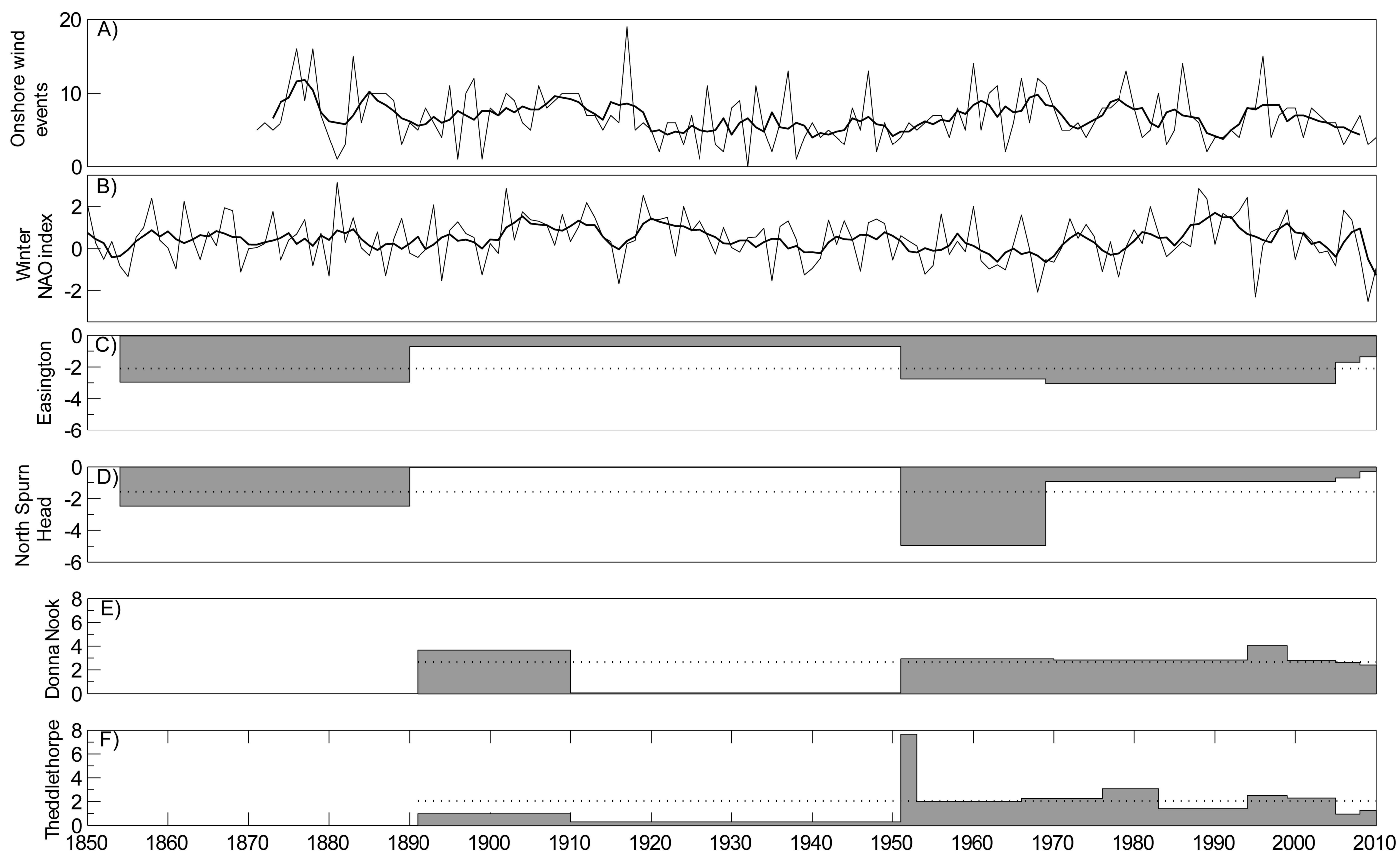


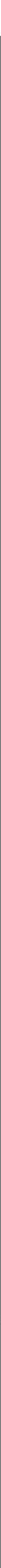

